NBER WORKING PAPER SERIES

CAPITAL CONTROLS AND RECOVERY FROM THE FINANCIAL CRISIS OF THE 1930S

Kris James Mitchener

Kirsten Wandschneider

Working Paper 20220

http://www.nber.org/papers/w20220

\author{
NATIONAL BUREAU OF ECONOMIC RESEARCH \\ 1050 Massachusetts Avenue \\ Cambridge, MA 02138 \\ June 2014
}

We thank conference and seminar participants at Oxford University, UC Davis, and the Bank of NorwayGraduate Institute of International Studies Conference for useful suggestions. Melissa Daniel and Rose York provided invaluable research assistance. The views expressed herein are those of the authors and do not necessarily reflect the views of the National Bureau of Economic Research.

NBER working papers are circulated for discussion and comment purposes. They have not been peerreviewed or been subject to the review by the NBER Board of Directors that accompanies official NBER publications.

(C) 2014 by Kris James Mitchener and Kirsten Wandschneider. All rights reserved. Short sections of text, not to exceed two paragraphs, may be quoted without explicit permission provided that full credit, including $(\subset$ notice, is given to the source. 
Capital Controls and Recovery from the Financial Crisis of the 1930s

Kris James Mitchener and Kirsten Wandschneider

NBER Working Paper No. 20220

June 2014

JEL No. E61,F32,F33,F41,G15,N1,N2

\begin{abstract}
$\underline{\text { ABSTRACT }}$
We examine the first widespread use of capital controls in response to a global or regional financial crisis. In particular, we analyze whether capital controls mitigated capital flight in the 1930s and assess their causal effects on macroeconomic recovery from the Great Depression. We find evidence that they stemmed gold outflows in the year following their imposition; however, time-shifted, difference-indifferences (DD) estimates of industrial production, prices, and exports suggest that exchange controls did not accelerate macroeconomic recovery relative to countries that went off gold and floated. Countries imposing capital controls also appear to perform similar to the gold bloc countries once the latter group of countries finally abandoned gold. Time series analysis suggests that countries imposing capital controls refrained from fully utilizing their newly acquired monetary policy autonomy.
\end{abstract}

\author{
Kris James Mitchener \\ Department of Economics \\ Leavey School of Business \\ Santa Clara University \\ Santa Clara, CA 95053 \\ and NBER \\ kmitchener@scu.edu \\ Kirsten Wandschneider \\ Department of Economics \\ Occidental College \\ 1600 Campus Rd \\ Los Angeles, CA 90041, U.S.A. \\ kirsten@oxy.edu
}




\section{Capital Controls and Recovery from the Financial Crisis of the 1930s}

\section{Introduction}

In 2010, the International Monetary Fund (IMF) revised its stand against capital controls, recognizing that sudden capital surges can pose risk for some countries, and acknowledging that controls on capital inflows may be part of a toolkit that countries use to ward off financial crises (Ostry et al, 2010). This change in policy reversed the previous IMF position favoring the free movement of capital. ${ }^{1}$ Nevertheless, the use of capital controls as a policy tool, especially as a stopgap to ward off financial crises, remains controversial. For example, in 1998, Malaysia was castigated by policymakers and financial markets for imposing capital controls in response to the East Asian financial crisis.

Since capital controls have been used in response to exchange rate crises, understanding their macroeconomic effects relative to other policies is an important agenda for research. On the one hand, capital controls bottle up inflows, which could potentially drive new investment spending and fuel a recovery in the wake of a crisis. On the other, their imposition could provide central banks with room for maneuver; in particular, central banks can maintain fixed exchange rates, but pursue expansionary monetary policy in the short run to stimulate output and return to long-run policy objectives. Research on the 1997-8 East Asian financial crisis has suggested that restrictions on the movement of capital may have produced a faster economic recovery in comparison to countries that relied on help from the IMF (Kaplan and Rodrik, 2002).

Determining the relative benefits and costs of capital controls for economic recovery is ultimately an empirical question, and the Great Depression offers a potentially fertile testing ground for shedding light on this issue. Deflation spread globally after 1929, and as production and incomes fell, countries found it increasingly difficult to maintain pegged exchanged rates. By the mid-1930s, most had abandoned the gold-exchange standard and were seeking refuge in a variety of alternative exchange-rate arrangements, including capital controls. The abandonment of gold, however, was carried out in a haphazard manner, with some countries following England off gold in 1931 and others steadfastly staying on gold until after 1933 (Eichengreen,

\footnotetext{
${ }^{1}$ For example, in 1998, in its World Economic Outlook, the IMF was critical of Malaysia's use of capital controls in response to the East Asian financial crisis (IMF, 1998, p.4). By 2011, deputy managing Director Nemat Shafik suggested that that Iceland keep its capital controls in place in response to the 2008-9 financial crisis (IMF, 2011).
} 
1992, Kindleberger, 1986). Some countries chose to re-peg at lower rates to particular currencies, such as the pound sterling, others floated their currencies, and many imposed exchange controls (i.e., the common name for capital controls in that era) in order to shield their economies from the effects of short-term capital flows ("hot money") and balance-of-payments pressures. $^{2}$

The Depression was the first financial crisis in the era of modern economic growth in which a large number of countries responded to balance-of-payments pressures by imposing restrictions on the movement of capital. Few, if any, financial crisis since the Depression have rivaled its severity and global impact, and few have witnessed so many countries responding by imposing capital controls, perhaps in part because many subsequent crises have been regional in nature (Glick and Rose, 1999). Previous research has found that de-linking from gold sped up recovery from the Great Depression (Choudhri and Kochin, 1980, Eichengreen and Sachs, 1985, Campa, 1990) and that imposing capital controls appears to have offered some relief from "golden fetters" (Obstfeld and Taylor, 1998). Extant studies, however, have yet to analyze systematically how countries imposing exchange controls performed relative to countries that stayed on gold (the so-called "gold bloc") and how countries imposing exchange controls performed relative to countries that exited gold and floated their currencies after abandoning the gold standard. For example, imposing capital controls might have prevented short-run capital flight and, under the "policy trilemma" framework, enabled policymakers more room to aid ailing banking systems using monetary policy. Moreover, imposing capital controls while maintaining a fixed exchange rate might have reduced the possibility that a dramatic decline in the value of the currency would further increase the probability of a banking crisis. On the other hand, if capital control countries kept their exchange rates pegged (perhaps due to a "fear of floating") or delayed an adjustment in their parity, then the scope to engage in a competitive devaluation to boost the domestic production of exports might be more limited relative to floaters.

\footnotetext{
${ }^{2}$ We use the terms capital controls and exchange controls synonymously throughout the paper. While the modern economics literature uses the term capital controls, the writings of the 1930s uniformly use the term exchange controls. This term referred to the original purpose of controls, restrictions on purchases and sales of foreign and domestic currency at market rates, but interwar controls on the movement of capital quickly grew to include restrictions on trade, travel, and the repatriation of capital gains, and hence why we use them interchangeably throughout.
} 
In order to fill these lacunae, we analyze the effects of capital controls on economic recovery in the 1930s by assembling a large, new monthly data set of macroeconomic variables and information on exchange rate and capital controls, spanning 1925-36, which contains almost all of the countries that were on the interwar gold standard. Our database classifies how and when countries abandoned the interwar gold standard as well as whether countries imposed exchange controls, enabling us to study a variety of counterfactuals and consider how the pace of recovery differed under alternative policy regimes.

We use these data to examine both their immediate effects on capital flight as well as their medium-term effects on economic recovery. Our empirical analysis takes advantage of the variation in timing of going off gold and heterogeneous policy responses in order to estimate the causal effects of exchange controls on economic recovery from the Great Depression. We employ time-shifted, difference-in-differences estimators to account for bias arising from the variation in timing of going off gold (i.e., when treatment began).

We first show that the capital controls achieved the short-run policy objective of stemming capital outflows. Gold cover ratios stabilized in the months following the imposition of capital controls. We then show that capital controls did not accelerate recovery from the Great Depression relative to countries that went off gold and floated. In examining the impact of capital controls on industrial production, exports, and prices, we only find statistically significant effects on industrial production, even after controlling for additional policy variables such as movements in the discount rate and changes in trade barriers. However, the estimated coefficient on industrial production suggests that capital controls slightly reduced its rate of growth relative to floaters. Thus, while capital controls provided an immediate tool to combat capital flight, they appear have held no advantage over a free float, and likely even hindered recovery after they were imposed.

The fact that exchange-control countries broke from the gold standard earlier than Gold Bloc countries meant that their recoveries began sooner; however, once the latter group also finally abandoned gold, our analysis shows that countries imposing capital controls did not experience faster growth in industrial production and export growth relative to the gold bloc. Exchange controls allowed countries that perhaps "feared floating" to maintain a fixed parity, but it offered scant improvement in terms of macroeconomic recovery. 
We explore the implications of our results - why capital controls did not stimulate recovery. Time series analysis suggests that countries imposing capital controls did not actively pursue expansionary monetary policy after abandoning gold. An examination of discount rate policy of capital control countries suggest that, while they did not follow France and continue to raise rates after imposing controls, they also did not pursue a discount rate strategy similar to the U.S., a country which floated and then aggressively pursued expansionary monetary policy. The average growth rate in the money supply of capital control countries turned positive after their imposition, but it was slower than the growth rates of either floaters or gold bloc countries once they finally abandoned.

The next section of the paper reviews existing research on exchange controls and relates it to the setting of this paper - the 1920s and 1930s. Section 3 employs a new panel level data set to quantify how capital controls influenced the paths of industrial production, exports, and prices relative to other policy regimes - countries that floated and countries that stayed on gold. Section 4 analyzes central bank policy rates to determine the extent to which countries exploited the "policy trilemma" and took advantage of the ability to conduct autonomous monetary policy once capital controls were imposed. It then provides a discussion as to why capital controls were maintained even after gold outflows subsided. Section 5 summarizes our findings on the effectiveness of capital controls in response to the crisis of the 1930s.

\section{Capital Controls and the Great Depression}

\section{A. Costs and Benefits of Capital Controls}

Capital controls limit the movement of currency and foreign exchange across borders. They come in many forms and are put in place with a variety of goals in mind. ${ }^{3}$ They share the feature of centralizing all dealings of foreign exchange in the hands of some government authority. The first widespread use of them occurred during World War I. At the outset of the war, belligerents tried to slow down the repatriation of capital so that foreign exchange could be used for purchasing strategic imports. These controls were also used as a means for raising

\footnotetext{
${ }^{3}$ For example, controls might be used to limit outflows of capital for balance of payments reasons, to preserve domestic savings or to allocate capital to specific sectors of the economy.
} 
revenue via higher inflation (delinking to gold and printing money) and as a tool for taxing wealth (Bakker, 1996).

In this paper, we study restrictions that were put in place as a reaction to balance-ofpayments pressures and, in particular, the threat of capital outflows. ${ }^{4}$ In currency crises, exchange controls are often employed as a response to anticipated or immediate danger of capital exports or repatriation of funds abroad. A League of Nations' study (1938, p.25) concluded that capital controls were initially adopted in the late 1920s and early 1930s in response to a deterioration in balance of payments conditions and observed or anticipated flight of capital. ${ }^{5}$

Some research has suggested capital controls have considerable utility in warding off financial crises. For example, Krugman (1998) argues that in the event of a crisis, temporary exchange controls can provide a country with time to restructure its financial sector in an orderly fashion, lower interest rates, and put pro-growth policies in place. Recent theoretical work has suggested that targeted capital controls could be used to provide some degree of control over macro policy management (Farhi and Werning (2012) and Schmitt-Grohe and Uribe (2012)), although the effectiveness of such controls, if used episodically, may depend on whether they are able to target a wide set of assets and act like a "wall" (Klein and Shambaugh, 2013). ${ }^{6}$ Others have pointed out that capital controls have a place in a world where free capital predominantly flows from poor to rich countries, rather than the reverse, and where unchecked capital flows can expose countries to excessive systemic risk (De Long, 2004). Blouin, Ghosal, and Muhan (2011) emphasize that arguments for capital controls are strongest when institutional state capacity is weak and the economic environment is uncertain, putting countries at risk for capital flight.

On the other hand, critics point to evidence that the controls are ineffective: markets figure out ways to circumvent restrictions on the movement of capital. For example, this situation was observed during Bretton Woods once restrictions on the current account were

\footnotetext{
${ }^{4}$ There is an equally large literature on the use of capital controls to ward off capital inflows, such as the use of them to limit real currency appreciations (Neely, 1999; Johnston and Tamirisa, 1998).

${ }^{5}$ Ellis (1947, p. 878-9) suggests that during the 1930s the most common form of exchange control was enforcement of overvalued exchange rates as a device to avoid depreciation, which would have ensued because of the withdrawal or flight of capital from debtor countries. Exchange controls were thus used to defend a particular exchange rate and ward off capital flight.

${ }^{6}$ Although not explicitly about financial crises, Farhi and Werning (2012) build a model where they consider the utility of capital controls in response to a variety of shocks. In numerical simulations, they find that capital controls are especially effective in response to risk premium shocks (interpreted as a shock to the world interest rate). Klein (2012), however, finds "episodic" capital controls used recently to regulate inflow-fueled exchange rate appreciations and potentially destabilizing asset price booms are ineffective.
} 
lifted. Critics also suggest that capital controls encourage corruption, hinder necessary policy adjustment in the time of a crisis, significantly raise trade costs and the cost of capital, and make it difficult to attract capital flows once the crisis period ebbs (e.g. Edwards, 1995; Wei and Zhang, 2007). Moreover, even if implemented in response to balance-of-payments crises, they can become permanent policy features that distort markets (Edwards, 1999).

Empirical research has attempted to quantify the relative benefits and costs of capital controls. For example, Alesina, Grilli and Milesi-Ferretti (1993) find little evidence that, in general, capital controls reduce long-run growth. Edwards and Rigobon (2009) re-examine the effects of restrictions on capital inflows (as in Chile's recent use of taxes on the movements of short-term portfolio investment), and suggest that these types of controls appear to reduce the vulnerability of the nominal exchange rate to external shocks.

What has received less attention from researchers is the analysis of how capital controls imposed in response to financial crises affect recovery. This may be due to empirical hurdles that make credible identification difficult, such as having too few observed cases of countries imposing capital controls in response to a single crisis or the problem of unobserved heterogeneity that arises from pooling observations across different crises. One recent attempt to overcome these challenges is Kaplan and Rodrik (2002), which uses difference-in-difference estimates to show that the one country that imposed capital controls in response to the 1997-8 East Asian Financial Crisis, Malaysia, experienced stronger recovery relative to countries receiving IMF programs.

\section{B. Exchange-Rate Responses to the Great Depression}

The global economic calamity of the 1930s ultimately led to the collapse of the interwar gold standard. ${ }^{7}$ As countries considered abandoning their pegged rates under the gold-exchange standard, they were confronted with the open economy macroeconomic policy trilemma (Obstfeld, Shambaugh and Taylor, 2004). ${ }^{8}$ That is, whereas gold-standard countries had previously embraced fixed exchange rates and capital mobility in exchange for limited monetary

\footnotetext{
${ }^{7}$ The interwar gold standard was often known as the gold-exchange standard because countries supplemented gold reserves with the foreign currency of other countries pegged to gold.

${ }^{8}$ Simmons (1997), Wandschneider (2008) and Wolf (2008) suggest that deflationary pressures, banking crises, gold reserves, and the prior experience of hyperinflation were important determinants in predicting the timing of when countries exited.
} 
policy sovereignty, abandoning the gold standard presented countries with new choices. They could: stay off gold permanently and float; devalue and re-peg at lower currency values; and/or put capital controls in place to give them some leverage over domestic monetary policy, perhaps with the hope of reflating their economies or injecting liquidity into weak or collapsing banking systems.

Table 1 summarizes when countries suspended operation of the gold standard, when they depreciated or devalued, and when they imposed exchange controls. For our analysis, we follow other researchers (including the League of Nations), and broadly classify countries into three groups: (1) those that abandoned gold and imposed capital controls; (2) those that abandoned gold by floating their currencies; and (3) those that remained on gold after 1934. The last group includes countries commonly classified as the "gold bloc": Belgium, France, the Netherlands, Poland, and Switzerland. Italy is classified as an exchange control country for the current analysis since it imposed exchange controls in May of 1934 (Dimitrova et. al., 2007). In addition to the gold bloc, the "gold stalwarts" (group 3) include Albania, Hong Kong, Lithuania and the Netherlands Indies, all of which abandoned gold in 1935 or later.

The second group, the "floaters," is comprised of countries in the Sterling bloc and those that abandoned gold without imposing capital controls. Since a primary goal is to understand how capital controls affected recovery from the Depression, we categorize Finland and the United States as floaters, despite both countries brief experience with exchange controls during this period. For Finland, the exchange control period was only three months - October to December 1931 - and it is seen as ineffective in stemming capital flight (Letho-Sinisalo, 1992). Similarly, exchange controls in the US are generally not considered effective as can be seen in the active forward market in US dollar. Since Portugal's capital controls were nominally in place since 1922, and since they were not used to manage a balance-of-payments crisis, we classify this country as a floater.

The group of exchange control countries comprises the largest group in our sample. It consists of Central and Eastern European countries, Latin American countries, Japan, and Iran. Bulgaria heavily relied on exchange controls to align itself with Germany after 1931, so we classify it as an exchange control country. In most countries, exchange controls took the form of administrative controls, with the government centralizing exchange dealings, setting official 
exchange rates, and hindering the transfer of capital abroad by private citizens to stop capital flight and curb speculation. Governments also took control of export proceeds and privately held foreign assets (Ellis, 1941).

\section{The Emergence of Capital Controls in the 1930s}

Nurkse (1944) corroborated the findings of the 1938 League of Nations study, suggesting that the principal reason most countries imposed capital controls in the 1930s was to curb the outflow of capital. ${ }^{9}$ Ellis (1941) also states that countries in this period explicitly used exchange controls to protect against capital flight and to defend parities that had become overvalued based on purchasing power parity values or international price comparisons. ${ }^{10}$

Many European countries opted for capital controls when confronted with banking crises in the spring and summer of 1931, falling foreign exchange reserves, and capital flight. Some countries appear to have been concerned that floating rates, without capital controls, would ignite hyperinflations similar to those seen in Continental Europe in the early 1920s. ${ }^{11}$ Germany is often cited as the most prominent example of a country that imposed extensive capital controls, creating a complex system of bilateral trade clearing agreements in the late 1930s after their imposition (Child, 1978; Neal, 1979). ${ }^{12}$ German capital controls were initially imposed to curb capital outflows and maintained in order to keep the official foreign exchange rates for the Reichsmark at the old parity; thereafter, an extensive trade clearing system was created to offset the distortionary price and trade effects of the capital controls. The clearing system was then utilized by the Nazi government in order to secure critical imports in the absence of foreign currency (US Tariff Commission, 1942). And when countries such as Germany and Hungary imposed exchange controls, some nearby trading partners felt pressure to follow suit (Ellis, 1941). Some primary-product exporting countries in South and Central America imposed

\footnotetext{
${ }^{9}$ Exceptions may have been Hungary, Greece, and Bulgaria, which appear to have implemented capital controls in 1931 to acquire foreign exchange for debt servicing (Nurkse, 1944)

${ }^{10}$ Quotas and restrictions on imports, used by France and other gold bloc countries, were an alternative means for maintaining overvalued parities (Nurkse, 1944). Harris (1936) takes a broader view, suggesting countries that devalued or imposed capital controls were the most likely to have overvalued currencies.

${ }^{11}$ Or less extreme, capital controls may have provided a more effective nominal anchor than stabilizing interest rates a la Calvo and Reinhart (2002).

${ }^{12}$ The German bilateral clearing agreements, set up by Hjalmar Schacht in 1934, relied on a system of managed accounts and fixed exchange rates to circumvent the need for gold and foreign assets. At its height, they expanded to 25 countries and covered about half of all German foreign trade (Neal, 1979).
} 
controls in response to balance-of-payment pressures and potential sovereign debt defaults (Bratter, 1939).

To assess whether capital controls had an effect on halting capital flight, we computed cover ratios for countries imposing capital controls. The cover ratio for each country is calculated as the ratio of central bank gold reserves and foreign currency assets to its domestic liabilities (defined as notes in circulation). Data are from the Statistisches Handbuch der Weltwirtschaft (1934, 1936-7). Figure 1 then centers each country's data based on the month on which it imposed exchange controls. As the graph shows, cover ratios declined dramatically in the 15 months prior to imposing controls, falling from around 70 percent to below 50 percent. In the months following the imposition of capital controls, the ratio then stabilizes and recovers somewhat suggesting that exchange controls proved effective in stemming capital flight.

\section{Analyzing how Capital Controls Influenced Recovery from the Great Depression}

\section{A. Cross-Sectional Evidence}

At the time of their imposition, the League of Nations viewed the widespread use of capital controls as troubling. While recognizing that controls halted capital outflows, the League became concerned that the long-term costs of maintaining them would outweigh their short-run benefits, suggesting that they would raise domestic prices and reduce exports (League of Nations, 1938). Foreman-Peck (1983) later estimated that, as of 1934, the currencies of exchange control countries were overvalued by as much as $60 \%$ relative to the pound and the dollar. Ellis (1939) suggests that exchange controls discouraged foreign investment by hindering capital repayments. He also claims that exchange control countries had lower output and trade than countries with depreciated currencies, outcomes we empirically test in our paper. On the other hand, Aldcroft and Oliver (1998) suggest that many exchange control countries expanded their trade through clearing agreements and were able to obtain higher prices for their exports in the clearing markets than in the world market (in effect, diverting trade).

Previous research has established that going off gold was linked to faster economic recovery (Eichengreen and Sachs, 1985 and Campa, 1990), but the focus of these studies was largely on identifying the pre- and post-effects of leaving the gold-exchange standard. 
Comparatively less attention has been paid to the precise way in which countries abandoned the gold standard. A few studies use cross-sectional data to suggest that countries, which chose to remain on the gold standard, had lower rates of growth in industrial production between 1929-35, but that this slow growth was mitigated by the use of exchange controls (Eichengreen, 1992; Obstfeld and Taylor, 1998). These same studies suggest that countries preserving fixed exchange rates were exposed to greater deflation, but find that deflation was less if they implemented exchange controls; however, they do not try to account for differences in the timing of the implementation of capital controls and how this might influence recovery.

We begin our analysis of the effects on recovery from the Depression by discussing our data and presenting some summary evidence on macroeconomic performance once countries abandoned gold. To do so, we hand collected monthly data from 1925-36 on industrial production, wholesale prices, and exports for a sample of 37 countries from the League of Nations (1937, 1938) and the Statistical Handbook of the World Economy (Statistisches Handbuch der Weltwirtschaft, 1934 and 1936-37). Our new database improves on existing interwar datasets by expanding coverage for the number of countries (Latin America and Asia, plus Europe), the number of years (1925 to 1936), and the frequency of data (monthly versus annual). Our sample includes all the major economies on the interwar gold standard as well as almost all other countries that had adopted gold during this period.

Figures 2-4 plot the change in the parity between 1929 and 1936 against industrial production, exports, and wholesale prices. The y-axis values are measured relative to 1929 values, with 1929 indexed at 100. As in Eichengreen and Sachs (1985) and Campa (1990), we find that countries with large post-1929 devaluations experienced stronger growth in all three measures, suggesting a reversal in the trends of the deflation and declining output and exports that had set in during the Great Depression. As shown in Table 1, countries' policy responses to the Great Depression differed. We thus examine the scatter plots for the three sub-groups: exchange control countries, "floaters," and "gold stalwarts" (those that remained on gold past 1934). Figures 5-7 show that the salutary effects documented in the first set of plots were strongest for the floaters. The scatter diagrams suggest that after abandoning gold (and up through 1936), exchange-control countries experienced only a slight recovery in industrial production, wholesale prices, and exports. 
To shed more light on the effects on the longer-run effects of capital controls, we present results from cross sectional regressions. In particular, we regress one of our macroeconomic outcome variables (industrial production, wholesale prices, or exports) on a constant, a dummy variable for exchange controls, a dummy variable for countries that remained on gold past 1934, and a normally distributed error term. Our sample period ends in 1936, which relative to previous studies, allows us to include more gold bloc countries in our analysis of post-gold standard period; however, the coding of policy regime is nearly equivalent to Obstfeld and Taylor (1998). Hence, we are able to replicate their analysis when restricting the sample period to end in 1935.

Columns 1-3 of Table 2 define the dependent variable as the total percentage change between 1929 and 1935 whereas columns 4-6 define it as the total percentage change between 1929 and 1936. For gold stalwarts, our results are similar to those reported in Obstfeld and Taylor (1998). As columns 1-3 show, countries that remained on the gold standard after 1934 experienced an 18 percent cumulative drop in industrial production and a 28 percent fall in prices, reflecting the deflationary pressures of staying on the gold standard in the 1930s. We also document an almost $40 \%$ drop in exports in 1935 compared to 1929. The results are similar when we the sample period is extended to 1936 (columns 4-6). By contrast, our results for exchange control countries differ from earlier studies, such as Obstfeld and Taylor (1998), which reported positive effects of exchange controls on output and wholesale prices. Between 19291935, we can identify no statistically significant effect of exchange controls on output, wholesale prices, or export performance. If we instead use 1936 as the last year of the sample period, exchange controls appear to have had no statistically significantly different effect on industrial production or wholesale prices relative to floaters. However, exchange controls do appear to have reduced exports by 21 percent relative to floaters. Unlike floaters, some exchange-control countries had little scope to increase their exports via competitive depreciation because they did not devalue (Bulgaria, Czechoslovakia, Germany, Hungary, and Latvia). Other exchange control countries devalued, but did so in a delayed fashion relative floaters, thus limiting their scope for tilting the terms of trade in favor of domestic production. A closer examination of the composition of trade shows that roughly 60 percent of exchange control countries' exports went to countries that floated and 70 percent of imports came from them (Harris, 1936). Hence, 
because of delayed devaluations or no devaluation, the majority of goods that exchange-control countries exported became relatively less competitive and the majority they imported became relatively more competitive. Moreover, because exchange-control countries did not adjust their parities to lower levels immediately after leaving gold, import prices did not rise to the same degree as they did in floating countries, thus limiting their potential impact on the general price level of the economy. Nevertheless, if capital-control countries pursued expansionary monetary policies after imposing exchange controls, then a more dramatic recovery in prices could have still ensued - a point we turn to later in the paper.

\section{B. Difference-in-Differences Estimates}

Cross sectional regressions confirm that abandoning gold accelerated economic recovery in the 1930s; however our larger sample of countries shows somewhat different effects for exchange control countries in comparison to previous studies. To explore these differences further and develop causal estimates, we exploit the panel nature of our data (i.e., monthly data on a large sample of countries) to construct difference-in-differences estimates of the effects of exchange controls on several macroeconomic outcome variables.

Our identification strategy takes advantage of the variation in the timing of gold standard abandonment and restrictions in the movement of capital to identify an average treatment effect on the treated. To reiterate, Table 1 displays the time-series variation in policy changes across countries. If such differences in timing are not accounted for, it can produce biased estimates of our "treatment" variable. To illustrate this point, consider the more recent 1997-98 East Asian financial crisis. Malaysia was still experiencing severe economic difficulties through the summer of 1998, at a time when neighboring countries were already recovering from the 1997 Asian crisis. Malaysia's capital controls, however, came into place later than South Korea or Thailand's IMF assistance. Once this difference in timing of the treatment is accounted for, Malaysia appears to have had a faster recovery with capital controls in comparison to those that received IMF assistance packages (Kaplan and Rodrik, 2002). Similarly for our interwar sample, a bias in the treatment effect would occur if one does not account for the variation in timing of when countries leave the gold standard or impose exchange controls. For example, gold stalwart 
countries are often found to have slow recoveries despite the fact that they did recover when they finally left gold.

To gain some insight into how differences in implementation might matter, we first plot the average monthly growth rates of industrial production, prices, and exports based on the policy choice after abandoning gold. Figures 8-10 show the before and after effects of leaving gold on industrial production, wholesale prices, and exports when we explicitly control for the month when each country departed gold. It is important to note that the results are not to be confused with the cross-sectional estimates shown in Table 2. The growth effects documented here solely measure the recovery of countries once countries left the gold standard or imposed exchange controls, even for the gold stalwarts. The graphs still confirm that growth rates increased, deflation ended, and exports rose as countries abandoned the gold standard; however, the relative degree of recovery differs significantly across the three groups. Figure 8 shows that growth increased for all three groups when countries abandoned the gold standard or imposed exchange controls, and this effect appears largest for the gold stalwarts. Before leaving gold, floaters showed the largest decline in growth rates. As seen in Figure 9, all three groups showed deflation while on gold, but deflationary effects were most severe for the floaters. Gold stalwarts exhibit the strongest upward trend in prices once they finally abandon gold. By contrast, exchange-control countries inflation rates are less pronounced and similar to floaters after going off gold. With respect to exports, growth declines by about 0.5 percentage points for all country groups while on the gold standard. Gold stalwarts exhibit the fastest recovery in exports after finally leaving gold. Exports for exchange control countries recover slightly more slowly than floaters.

To explicitly account for variation in the timing of gold standard abandonment and policy choice and control for unobservable differences across countries, we estimate a time-shifting, difference-in-differences model of the following form:

(1) $y_{\mathrm{it}}=\alpha_{\mathrm{it}}+\beta$ OffGold $_{\mathrm{it}}+\gamma$ OffGold $_{\mathrm{it}} *$ XControls $_{\mathrm{i}}+$ oOffGold $_{\mathrm{it}}$ SStalwart $_{\mathrm{i}}+X_{\mathrm{it}}+C_{\mathrm{i}}+$ Month $_{\mathrm{t}}+\mu_{\mathrm{it}}$,

where $y_{\mathrm{it}}$ is one of our three measures of macroeconomic performance (growth in industrial production, the wholesale inflation rate, or export growth). OffGold it is a time-varying dummy 
variable that indicates the time off gold for each country. It equals one in all the months following a country's decision to devalue and/or officially suspend the gold standard (thereby leaving gold de jure or de facto) or impose exchange controls. XControls $\mathrm{s}_{\mathrm{i}}$ is a dummy variable for exchange controls as defined in Table 1a. Stalwart $t_{i}$ is a dummy variable for the countries that remained on gold through the end of 1934 as defined in Table 1c. $X_{\mathrm{it}}$ are additional time-varying country-specific controls, $C_{\mathrm{i}}$ are country fixed effects, which absorb the time-invariant dummies for Gold $_{\mathrm{i}}$ and XControls. $\mathrm{i}_{\mathrm{i}}$. Month $\mathrm{t}$ are time fixed effects, and $u_{i, t}$ is a white-noise error term. We estimate models where the omitted category is the floaters - countries that leave the gold standard before the end of 1934 and do not impose exchange controls thereafter. Our counterfactual estimates thus focus on the effects for two treatment groups, exchange-control countries and the stalwarts, relative to floaters. ${ }^{13}$ In this specification, $\beta$ describes the percentage point change (log points) of the effect of leaving the gold standard for the omitted category. $\gamma$ and $\sigma$ respectively estimate the effect of going off gold for the exchange control countries and the gold stalwarts relative to the omitted group.

Table 3 presents estimates of equation (1), with standard errors of the estimated coefficients clustered at the country level. For floaters, going off gold raises the growth rate in industrial production by $1.1 \%$, increases monthly wholesale inflation by $0.7 \%$ and stimulates export growth by $1.8 \%$ Relative to floaters, exchange control countries see a smaller boost in industrial production of $0.7 \%$ per month, but no statistically significant different effect with respect to inflation and exports. Relative to floaters, gold stalwarts exhibit a statistically significant increase of $1.3 \%$ per month in wholesale prices when they finally leave gold, but no statistically significant effect with respect to industrial production or exports.

As a robustness check, we considered some additional specifications, including adding controls to understand whether our effects are related to the capital controls themselves or to other economic characteristics of the economies that scholars have suggested might matter. As Table 3 shows, the one-month lagged discount rate as well as a measure for trade protection to capture the effect that countries might have substituted exchange rate policy for trade policy, does not alter the point estimates significantly. ${ }^{14}$ Ellis (1947) noted that some countries that

\footnotetext{
${ }^{13}$ These counterfactuals follow naturally from the time-shifting, diff-in-diff identification strategy.

${ }^{14}$ Data on trade protection come from Lampe and Sharp (2013) and use the import-weighted average ad valorem tariff, calculated as the ratio of customs duty revenue to total imports for domestic consumption. For discount rates,
} 
imposed capital controls had "overvalued" parities. If this were the case, then it is possible that the capital control we consider is proxying for the fact that these countries had uncompetitive exchange rates ex ante. We therefore tried a specification where we scaled the capital control dummy by the exchange rate relative to the dollar as of the start of the Depression. If the exchange rate is important, then the estimated coefficient on this variable should be negative and significant. We therefore ran some specifications where we took into account the various sizes of countries' devaluations as well as countries' debt levels. These specifications yielded similar results, showing no systematic evidence that exchange controls boosted recovery relative to other policy choices. ${ }^{15}$

\section{Endogeneity of Exchange Controls}

Our findings suggest that, in terms of macroeconomic performance, exchange control countries did no better than either floaters or gold stalwarts. It is possible, however, that a country's decision to implement capital controls is non-random, in which case the estimates reported in Table 3 might suffer from selection bias. To address the selection issue econometrically, we compare our baseline results to some additional specifications. Columns 1-3 of Table 4 show regression results from a different fixed effects model, one that excludes time dummies such that the identifying variation comes only from the time dimension. For the interaction between capital controls and going off gold, the results are similar to what is shown in the baseline specification of Table 3; of the three macroeconomic outcome variables, only industrial production is statistically significantly different from zero and the sign and size on the IP coefficient is nearly identical to the baseline regression. Because the source of identifying variance is quite different for these estimates, they provide some additional evidence that selection bias is not likely driving the findings with respect to capital controls.

We next employ a standard instrumental variables procedure to deal with the possibility that countries non-randomly selected whether they would impose capital controls or float when going off gold. Decisions about exchange-rate regime choices in the late nineteenth and early twentieth centuries were dominated by concerns about price stability (Ellis, 1939, p.33). We

\footnotetext{
we tried alternative lag structures, including two and four months, and results were similar to those reported.

${ }^{15}$ Results for these additional specifications are omitted to save space, but are available from the authors upon request.
} 
therefore use the change in a country's price level between 1913-1922 as an instrumental variable. Since changes in prices during the period 1913-22 are largely associated with wartime disruptions to markets and the end of wartime price controls, they represent a plausibly exogenous shock that tempered the decision about whether to impose capital controls or to float. Moreover, price dynamics under the reconstituted interwar gold standard were fundamentally different from the price movements in the floating period before 1922: there is no direct effect from the 1913-22 price changes on industrial production, wholesale prices, and exports under the gold standard regime. Countries that experienced high inflation or hyperinflation may have been especially reluctant to abandon the gold standard in the 1930s (given the classical gold standard era was associated with price stability) and thus tended to impose capital controls rather than float (a decision that was associated with runaway inflation of the 1910s and early 1920s). Because capital controls appear twice in our specification (i.e., also in the interaction term), we create a second instrument that is the interaction between off gold and a country's change in prices between 1913-22. ${ }^{16}$ First stage results show that the sign on the changes in prices between 1913-22 is positively related to being a country with capital controls as predicted. The AngristPischke multivariate $F$ tests of excluded instruments average 11.1 for the first instrument and 15.0 for the second instrument when looking across the three outcome variables. ${ }^{17}$

To implement the IV strategy, we include time dummies but exclude country fixed effects. ${ }^{18}$ Thus, in contrast to columns 1-3 of Table 4, these estimates identify off of the crosssectional variation in the data. As shown in columns 4-6 of Table 4, and as reported in other specifications, we find no ameliorative effects from capital controls. The coefficient estimates for industrial production and wholesale prices are fairly similar to those reported in other specifications. Only when we consider exports is the coefficient on capital controls somewhat different. It is statistically significantly different from zero; however, the sign is negative.

\footnotetext{
${ }^{16}$ An alternative IV approach would be to specify a model that looks like Columns 1-3 of Table 3, but includes only the latter instrument, i.e. the time-varying instrument. Estimates for the three outcome variables look similar to those reported in columns 4-6 of Table 4.

${ }^{17}$ The corresponding Angrist-Pischke underidentification tests have p values between 0.0000 and 0.006 .

${ }^{18}$ The sample sizes are somewhat smaller in the IV regressions due to missing data on the changes in prices for the period 1913-22.
} 
Adding the two coefficients, the IV estimate suggests that, on average, capital controls reduced exports by a little less than $1 \%$ per month relative to floaters. ${ }^{19}$

Finally, because IV approaches always depend on the (untestable) economic validity of the instruments, it is worth considering the direction of the potential bias and what it would imply for the analysis. If countries that selected into capital controls were systematically performing worse than floaters at the time when they abandoned gold, then the reported coefficients could potentially be understating the size of the effect that capital controls had on recovery from the Great Depression. However, as Figures 8-10 show, the average decline in prices, industrial production, and exports for capital countries prior to their implementation was smaller in comparison to floaters prior to departing gold. Hence, selection would be positive relative to floaters, and lead to a slight overstatement of the size of the ameliorative effects. Because we observe no measurable macroeconomic benefits of capital controls, any potential bias not accounted for by our different estimation methods thus seems harmless to the main thrust of the results.

\section{Why Were Capital Controls Ineffective at Boosting Recovery?}

\section{A. Policy Rate Interdependence}

Our difference-in-difference regression estimates suggest that, relative to floaters, countries imposing exchange controls exhibit no statistically significant difference in exports or wholesale prices and show a somewhat smaller recovery in industrial production. These findings are consistent with Ellis' (1939) untested claim that capital controls discouraged foreign investment and that capital control countries showed slower output growth. In the framework of the international macroeconomics policy trilemma, this result might seem surprising since countries imposing capital controls had policy flexibility after abandoning gold, and therefore should have performed at least as well as the floaters. For example, in the presence of capital controls, they could now conduct monetary policy with the aim of injecting liquidity into banking systems, reflating prices, or stimulating output. Although he does not formally test it, in his study of the interwar gold standard Nurkse (1944, p.169), suggests countries may have kept

\footnotetext{
${ }^{19}$ When we consider the equivalent specification, but without instruments, results are similar to those reported in Tables 3 and 4.
} 
exchange controls in place to "permit the adoption of monetary expansion at home or to at least avert the need for further deflation."

To understand why we fail to see faster macroeconomic recovery, we analyze the extent to which exchange-control countries availed themselves to autonomous monetary policymaking after they change their policies by examining interest rate interdependence with key gold standard countries. That is, if capital controls are tight, under fixed exchange rates it is not necessary for a country's interest rate to equal the base rate, given policymakers some room for maneuver. ${ }^{20}$ We thus analyze changes in each capital control country's discount rate (i.e., policy variable) to changes in a base country's discount rate (meant to represent a benchmark rate that policymakers in other countries would have followed in order to maintain gold convertibility).

In particular, we examine the monthly movements of bank rates or discount rates before and after capital controls were put in place since this was the policy variable that most central banks targeted during our sample period (Eichengreen, 1992). ${ }^{21}$ We focus on the behavior of changes in discount rates or bank rates (as denoted by $\Delta$ in the equation below) since results from Augmented Dickey Fuller (ADF) tests cannot reject the null hypothesis of unit roots or near unit roots in many of the bank rate series. ${ }^{22}$ For all countries imposing capital controls for which we have data, we regress (in first differences) the discount rate for the country with capital controls, $i$, on a constant term, the discount rate in a base country (Base), a dummy variable for when capital controls are imposed (XControls), the interaction between the base country's discount rate and the capital control indicator variable, and a white-noise error term:

(2) $\Delta i_{\mathrm{t}}=\alpha_{\mathrm{t}}+\beta X$ Control $_{\mathrm{i}}+\gamma \Delta B A S E_{\mathrm{t}}+\sigma \Delta B A S E_{\mathrm{t}} *$ X $_{\text {Control }}+\mu_{\mathrm{t}}$

We test whether the dummy variable indicating the presence of capital control interacted with the base rate is statistically significant different from zero, i.e. whether a given country was

\footnotetext{
${ }^{20}$ Alternatively, one could think of this as a wedge between a country's interest rate and the base rate, where the capital control is a tax on foreign borrowing that affords the country with monetary policy autonomy. See Farhi and Werning (2012) and Schmitt-Grohe and Uribe (2012).

${ }^{21}$ As a check on whether countries followed the base rate, we ran a panel regression of changes in discount rates for all countries in our sample (not just exchange control countries) on a constant term and changes in England's bank rate for the pre-1929 period. We found the coefficient on the base rate to be positive and statistically significant. ${ }^{22}$ Using ADF tests on the discount rates, we cannot reject the null hypothesis of a unit root in levels for all countries except for Austria and Hungary. We reject the null hypothesis of a unit root for all countries in first differences.
} 
following the base country more or less after capital controls were imposed. The base policy rate in the regression represents either the United States or France, two countries which were at the core of the interwar gold standard and which had accumulated large amounts of gold prior to 1929. After 1933, the choices of these two base countries diverge, with the U.S. floating and France staying on gold, so this allows us to examine the monetary policy of capital control countries relative to a base country which was a floater and a base country that stayed on gold. That is, the efficient monetary policy choice of a given capital control country might not have been entirely orthogonal of the decision made by a floater like the U.S.

Table 5 displays regression based on estimating equation (2). ${ }^{23}$ Comparisons of each capital control country relative to the base-country France allow us to see if the discount rate policies of capital control countries diverged significantly from the "stayers." If this were true, then the sign on the interaction should be negative and statistically significant. As shown in the first column of results, we observe no such relationship. The interaction term is never statistically significant different from zero. The next column examines the relationship relative to the U.S. Positive and statistically significant coefficients would suggest that capital control countries followed the U.S., which pursued very expansionary monetary policy after leaving gold (Romer, 1992). Again, the interaction term is never statistically significant,

As a robustness check, columns 3 and 4 include England and Germany as alternative base countries. Although the U.S. and France were linchpins of the interwar gold standard, they were not the most important trading partner for some countries; since exchange controls can affect both the financial account and the current account, it may be that some countries monetary policies in turn followed their principal trading partners even after capital controls were imposed. Many countries in Central and Eastern Europe, for example, had close trade ties to Germany. ${ }^{24}$ That said, using England and Germany as base countries, the results similarly show no systematic evidence of changing discount rate policies after capital controls were imposed.

We can exploit the panel nature of our data by pooling the countries together and retesting the model with standard errors clustered at the country level. We report the findings using monthly differences in interest rates, however, the signs and significance of the interaction

\footnotetext{
${ }^{23}$ Standard errors are Newey-West corrected for serial correlation.

${ }^{24}$ Eichengreen and Irwin (1995) as well as Ritschl and Wolf (2003) document the breakup of the interwar gold standard into trade and currency blocs after its collapse.
} 
variable are virtually identical when we instead used annual differences. ${ }^{25}$ Panel B of Table 5 shows pooled regression results using the U.S., France, and England as base countries. The additional power from pooling shows up in that we now find some significant results. With respect to France, we see that capital countries do not follow France after they impose capital controls; the coefficient is negative and statistically significant at the 5\% level. Since France continued to raise rates to defend the gold standard until it departed in 1935, it is in many ways not surprising that there is a negative relationship with this base country. Next, consider the coefficient on the capital control interaction when England is the base country, which is positive and significant at the $10 \%$ level. While this suggests that countries followed the UK after imposing capital controls, it also reflects discount rate inaction. England lowered the rate through early 1932, but then held the rate absolutely fixed after it re-pegged (it pursued a one-shot devaluation). When we compare capital control countries to the U.S., the interaction term is also negative and significant at $10 \%{ }^{26}$ At best, one can conclude that policy rates in capital control countries did not blindly follow France into further monetary tightening. At worse, one could conclude they also did not follow the U.S. expansionary strategy.

\section{B. Further Evidence on Monetary Policy}

As has been widely noted by economic historians, the financial crisis of the 1930s manifested itself as twin crises in many countries (Grossman, 1994; Eichengreen, 1992; Grossman and Meissner, 2010). Countries that imposed capital controls found themselves with the policy freedom to aid weak banking systems that they would not have had if they had stayed on gold. As noted, central banks could have lent at lower rates (though we found little evidence that they did) or governments could have injected liquidity by increasing the money supply, perhaps by monetizing gold flows (as was done by the U.S. Treasury after 1933). Figure 11 therefore plots the average money growth rates (M0) for the three groups in our sample, before and after countries in each group left gold. Although money supplies grew at an average rate of $0.45 \%$ per year after countries imposed capital controls, this group experienced the slowest rate of growth after departing gold. Both floaters and stayers had faster rates of money growth after

\footnotetext{
${ }^{25}$ The annual regressions are a useful robustness check since adjustment speeds may not be instantaneous. Annual differences help smooth out differing speeds of adjustment.

${ }^{26}$ Since Germany was a capital control country, the results would be difficult to interpret if it were used as a base country in the pooled regression.
} 
exiting the gold standard. ${ }^{27}$ If banks did not receive adequate liquidity support in the wake of crises, this might have delayed recovery. However, if the countries that imposed capital controls were particularly concerned with price stability (as the first stage of our IV suggests), this might help explain why they failed to embrace their policy freedom and use it to help domestic banking systems.

As a final test of the conduct of monetary policy after the imposition of capital controls, we looked at whether covered interest parity (CIP) held. In particular, we examined the implied profit opportunities that existed if CIP conditions were not met. Violations of CIP indicate arbitrage opportunities, or in our case, that capital controls could have potentially been used to maintain an interest rate different from the global interest rate. Evidence of such differences could suggest that monetary policy was employed to stimulate the domestic economy. Unfortunately, data on forward exchange for our sample period exist for just seven countries, only two of which (Italy and Germany) imposed capital controls and kept them in place for more than a year; hence, the conclusions one can draw from this exercise are more limited. ${ }^{28}$ However, based on this limited sample, we find little evidence from either the time series plots or structural break tests that the behavior of implied profits from interest rate arbitrage for capital control countries were any larger or persisted longer in comparison to, for example, other gold bloc countries that did not impose them and instead devalued. ${ }^{29}$

\section{Why did Countries Maintain Capital Controls?}

As noted, primary sources from the interwar period suggests that policymakers initially imposed capital controls to stop capital flight; however, once the outflows abated, why did countries keep the controls in place? Indeed, many policymakers at the time were opposed to their maintenance. For example, the Bank for International Settlements which, even in its infancy attempted to coordinate central bank activity, thought the maintenance of capital controls stood in the way of reconstituting the gold standard; the BIS thus viewed exchange controls as partly responsible for delaying recovery from the Depression (BIS, Annual Report, 1935, 1936).

\footnotetext{
${ }^{27}$ To be clear, similar to Figures 8-10, the "off gold" period for the stalwart countries only refers to the months in 1935 and 1936, in which these countries had also abandoned the gold standard.

${ }^{28}$ The five others are Belgium, Holland, France, Switzerland, and the U.S. Data are forward exchange are from Einzig (1934) and interest rate data from Obstfeld, Shambaugh, and Taylor (2004).

${ }^{29}$ Results are available upon request.
} 
One reason we examine the somewhat longer-term effects of capital controls is that they may have afforded additional room for maneuver given the constraints of the policy trilemma. Our econometric evidence (albeit ex post) suggests capital controls had little effect on economic recovery in the 1930 s relative to other policy options. Further, our examination of monetary policy seems to indicate that central banks did not substantially alter their discount rate policies or dramatically increase their money growth rates.

As a proximate explanation, some exchange-control countries may have simply feared floating (Calvo and Reinhart, 2002) and kept them in place alongside a peg to provide a stable nominal anchor. The historical record points to several additional reasons why exchange controls may have been maintained once gold-cover ratios stabilized. Although the initial focus was on using them to contend with pressure on the financial/capital account, their persistence can likely be attributed to concerns over the current account (likely reflecting exchange rates that were still managed and overvalued) rather than an as an explicit tool to reflate economies and further stabilize banking systems. As global trade collapsed and export earnings fell (due to falling aggregate demand, rising trade barriers, and falling prices), the demand for foreign exchange grew. One way to ensure that foreign exchange needs of governments could be met was to restrict imports via quotas, import restrictions, and import substitution policies (Fishlow 1972, Thorp, 1984). Another way to limit imports, however, was exchange controls. As Eichengreen and Irwin (2010, pp.879) emphasize, "If the exchange controls were comprehensive and effective, they could be administered in a manner that left no need for additional measures such as tariffs or quotas. Import licensing and government allocation of foreign exchange meant that officials could determine the total amount of spending on imports and the allocation of that spending across different goods and country suppliers. Therefore, a country imposing exchange controls might not have to resort to higher tariffs and quotas because it already had the ability to limit imports through administrative action."

As the decade progressed, it became increasingly clear that exchange controls were working in conjunction with tariffs and quotas to restrict imports. Imports were often forbidden without an exchange permit guaranteeing the distribution of foreign currency to pay for them. "Traders were at liberty to import...but when it came to paying for the goods they often found their exchange applications were met only in part or only after a long delay. This was the origin 
of the 'blocked' commercial balances which many countries, whether or not they practiced exchange control themselves, accumulated in their dealings with exchange-control countries, and these blocked claims led to the use of clearing, funding or other arrangements designed to liquidate them. As a result, there was a marked tendency for exchange and trade controls to be more closely integrated" (Nurkse, 1944, p.175).

In addition, large external debt positions created ongoing demand for foreign exchange. The American stock market boom, however, began to seriously drain liquidity from borrowing regions toward the end of the $1920 s .{ }^{30}$ By 1929, after the Federal Reserve increased short-term rates, investors found domestic bonds increasingly attractive. U.S. net short-term and long-term lending turned negative (Eichengreen and Portes, 1990), and net external debtors (including the British Colonies, Eastern and Central Europe, and Latin America) found themselves scrambling to maintain sufficient foreign exchange to pay the interest on their loans abroad. Global commodity prices collapsed at around the same time (Lewis, 1949), compounding the debt servicing problem for many of these primary-product producers and triggering a compression of imports and current expenditures. As the global economic situation deteriorated in the early 1930s, exchange controls became a means for acquiring the currency to service debt. Government officials in Hungary, Greece, and Bulgaria imposed capital controls in 1931 to fend off debt default, and Latin American countries kept capital controls in place after outflows subsided in a futile attempt to avoid defaulting on external debt.

Countries also turned to clearing arrangements to earmark export earnings for debt service. For example, Western European creditor countries that ran bilateral trade surpluses with Germany could use the proceeds out of exports to service German loans via compulsory clearing arrangements (Nurkse, 1944). ${ }^{31}$ Similarly, England used the stick of the Ottawa Agreements of 1932 (which gave preference to Commonwealth and Empire exports) and the carrot of the 1933 Roca-Runciman Treaty (granting Argentina favored access to these same markets) to secure Argentine payments on its British held foreign debt (Eichengreen and Portes, 1990).

\footnotetext{
${ }^{30}$ The U.S. and U.K. accounted for roughly two-thirds of all gross foreign investment during the interwar period, with much of the U.K. investment channeled to the colonies or dominions (Eichengreen and Portes, 1986).

${ }^{31}$ More than a quarter of Europe's gross foreign obligations (excluding war debts and reparations) was German external debt. It had continued to borrow heavily between the Dawes Loan and when it imposed capital controls in 1931. (Eichengreen and Portes, 1986)
} 


\section{Conclusion}

The global economic crisis of the 1930s left an indelible mark on the evolution of the world economy. One lasting remnant was restrictions on the movement of capital or "hot money." (It took until the 1980s for capital flows to regain their importance in the global economy.) In this paper, we describe how capital controls first emerged in the 1930s as a response to capital flight during a global financial crisis, and show that they appear to have succeeded in slowing down capital flight by stabilizing gold cover ratios. Because capital controls were not removed, we are able to examine whether they accelerated the recovery from the crisis of the 1930s. Results from time-shifted, difference-in-differences regressions suggest that countries that used capital controls fared worse than floaters and no better than the goldstandard stalwarts - those gold bloc countries that steadfastly maintained gold into the mid1930s. Capital controls do not appear to have stimulated recovery from the Great Depression.

Capital controls gave central banks additional scope to pursue autonomous monetary policy while maintaining fixed exchange rates; however, we find little evidence that countries took full advantage of this policy freedom. Interest-rate behavior relative to key gold interwar standard countries like France and the U.S. does not suggest a bold break, rather a more muted response of not following gold bloc countries down the path of further raising rates. Moreover, money supplies of capital control countries did not grow more quickly in comparison to other policy choices. For the countries that imposed capital controls in 1931 and 1932, these findings are consistent with a large body of research suggesting that monetary policies were far too tight in the early 1930s (Eichengreen, 1992; Temin, Friedman and Schwartz, 1962; Temin, 1989) promoting deflation and, in some cases, contributing to the collapse of banking systems. In contrast, countries that moved to floating rates pursued expansionary monetary policies and appear to have halted further deflation and declining incomes and production.

Capital controls appear not to have been successfully utilized as tools for rescuing banking systems, stimulating domestic output, or for raising prices. Rather they appear to have been maintained as a means for restricting trade (working alongside or in lieu of restrictions on imports) and repayment of foreign debts. While our analysis suggests capital controls provided little macroeconomic benefit relative to other policies that were implemented in the 1930s, it 
would be difficult to conclude that they would have no ameliorative effects in other crises if employed with that purpose in mind. On the other hand, the experience of the 1930s suggests capital controls are often implemented with very short-run objectives in mind - to prevent capital flight. If kept in place, however, macroeconomic objectives can end up sharing the stage with other goals of policymakers.

\section{REFERENCES}

Alesina, Alberto, Vittorio Grilli and Gian Maria Milesi-Ferretti. (1993). "The Political Economy of Capital Controls." NBER Working Paper 4353 (May).

Bakker, Age F.P. (1996). The Liberalization of Capital Movements in Europe: the Monetary Committee and financial integration 1958 - 1994. Dordrecht, Netherlands: Kluwer.

Bank of International Settlements (1935/36/37). Annиal Report. Basel, Switzerland.

Bernanke, Ben S. (1995). "The Macroeconomics of the Great Depression: A Comparative Approach.” Journal of Money Credit and Banking 27(1): 1-28.

Blouin, Arthur, Sayantan Ghosalyand, and Sharun W. Mukand. (2011). "Globalization and the (Mis)Governance of Nations." Working Paper, University of Warwick (December).

Bratter, Herbert M. (1939). Foreign Exchange Control in Latin America. New York: Foreign Policy Association.

Calvo, Guillermo and Carmen Reinhart. (2002). "Fear Of Floating," Quarterly Journal of Economics 107(2): 379-408.

Campa, José Manuel (1990). "Exchange Rates and Economic Recovery in the 1930s: An Extension to Latin America," The Journal of Economic History 50(3): 677-682.

Child, Frank (1978). The Theory and Practice of Exchange Control in Germany Arno Press: New York.

Choudhri, Ehsan U. and Levis A. Kochin. (1980). "The Exchange Rate and the International Transmission of Business Cycle Disturbances: Some Evidence from the Great Depression." Journal of Money, Credit and Banking, 12(4): 565-574.

DeLong, J. Bradford (2004). "Should we still Support Untrammeled Capital Mobility?" Economists' Voice B.E. Press 1(1).

Dimitrova, K., N. Nenovsky and G Pavanelly. (2007). "Exchange Control in Italy and Bulgaria in the Interwar Period: History and Perspectives." Working paper International Centre for 
Economic Research (April).

Edwards, Sebastian (1995). "Introduction." In Capital Controls, Exchange Rates, and Monetary Policy in the World Economy, (Sebastian Edwards (ed.) Cambridge: Cambridge University Press.

Edwards, Sebastian (1999). "How Effective are Capital Controls?" Journal of Economic Perspectives 13(4): 65-84.

Edwards, Sebastian and Roberto Rigobon (2009). "Capital Controls in Inflows, Exchange Rate Volatility and External Vulnerability.” Journal of International Economics, 78(2): 256-267.

Eichengreen, Barry and Richard Portes (1986). "Debt and default in the 1930s: Causes and Consequences." European Economic Review 30(3): 599-640.

Eichengreen, Barry and Jeffrey Sachs (1985). "Exchange Rates and Economic Recovery in the 1930s." The Journal of Economic History 45(4): 925-946.

Eichengreen, Barry and Richard Portes (1990). "The Interwar Debt Crisis and Its Aftermath." The World Bank Research Observer 5(1): 69-94.

Eichengreen, Barry. (1992). "The Origins and Nature of the Great Slump Revisited." Economic History Review 45(2): 213-239.

Eichengreen, Barry (1992). Golden Fetters: The Gold Standard and the Great Depression, New York: Oxford University Press.

Eichengreen, Barry and Douglas Irwin (1995). "Trade blocs, currency blocs and the reorientation of world trade in the 1930s." Journal of International Economics 38: 1-24.

Eichengreen, Barry and Douglas Irwin (2010). "The Slide to Protectionism in the Great Depression: Who Succumbed and Why?" Journal of Economic History 70(4): 871-897.

Einzig, Paul (1934). Exchange Control. London: Macmillian.

Ellis, Howard S. (1939). "Exchange Control in Austria and Hungary." The Quarterly Journal of Economics 54(1): 1-185.

Ellis, Howard S. (1941). Exchange Control in Central Europe, Cambridge: Harvard University Press.

Ellis, Howard S. (1942). "The Problem of Exchange Systems in the Postwar World." American Economic Review 32(1): 195-205. 
Farhi, Emmanuel and Ivan Werning. (2012). "Dealing with the Trilemma: Optimal Capital Controls with Fixed Exchange Rates.” NBER Working Paper 18199.

Fishlow, Albert (1972). “Origins and Consequences of Import Substitution in Brazil.” In L. de Marco, ed., International Trade and Development. New York: Academic Press.

Foreman-Peck, James (1983). A History of the World Economy: International Economic Relations since 1850.

Friedman, Milton and Anna Schwartz. (1963). A Monetary History of the United States, 18671960. Princeton, NJ: Princeton University Press.

Glick, Reuven and Andrew K. Rose (1999). "Contagion and Trade: Why Are Currency Crises Regional?” Journal of International Money and Finance 18(4): 603-17.

Grossman, Richard. (1994). “The Shoe That Didn't Drop: Explaining Banking Stability During the Great Depression.” Journal of Economic History 54(3): 654-82.

Grossman, Richard and Christopher Meissner. (2010). "International Aspects of the Great Depression and the Crisis of 2007: Similarities, Differences, and Lessons." Oxford Review of Economic Policy 26(3): 318-38.

Harris, S.E. (1936). Exchange Depreciation: Its Theory and its History, 1931-35 with some Consideration of Related Domestic Policies. Cambridge: Harvard University Press.

International Monetary Fund. (1998). World Economic Outlook. Washington: IMF.

International Monetary Fund. (2011). IMF Survey Magazine: Countries and Regions, November 3.

Kaplan, Ethan and Dani Rodrik (2002). "Did the Malaysian Capital Controls Work?" In Preventing Currency Crises in Emerging Markets, Sebastian Edwards and Jeffry Frankel (eds.). Chicago: University of Chicago Press \& NBER.

Kindleberger, Charles P. (1986). The World in Depression, 1929-1939. Berkeley: University of California Press.

Klein, Michael and Jay Shambaugh. (2013). "Rounding the Corners of the Policy Trilemma: Sources of monetary policy autonomy." NBER Working Paper 19461 (September).

Klein, Michael. (2012). "Capital Controls: Gates and Walls," Brookings Papers on Economic Activity, vol.2 (Fall): 317-55. .

Krugman, Paul. (1998). “Saving Asia: It's Time to get Radical,” Fortune September 7: 74-80. 
Lampe, Markus and Paul Sharp. (2013). "Tariffs and Income: A Time Series Analysis for 24 Countries," Cliometrica, vol.7, issue3, pp. 207-235.

League of Nations. (1937). Monetary Review, Money and Banking 1936/37, Volume 1, Geneva: League of Nations.

League of Nations. (1938). Report on Exchange Control. Geneva: League of Nations.

League of Nations. (various years). Yearbook., Geneva: League of Nations.

Lehto-Sinisalo, Päivikki. (1992). “The History of Exchange Control in Finland.” Bank of Finland Discussion Paper.

Lewis, W. Arthur. (1949). Economic Survey, 1919-1939. London: Allen \& Unwin.

Neal, Larry. (1979). The Economics and Finance of Bilateral Clearing Agreements: Germany, 1934-1938," Economic History Review 32: 391-404.

Nurkse, Ragnar (League of Nations). (1944). International Currency Experience: International Currency Experience. Princeton, NJ: Princeton University Press,

Obstfeld, Maurice and Alan M. Taylor. (1998). "The Great Depression as a Watershed: International Capital Mobility over the Long Run." In The Defining Moment: The Great Depression and the American Economy in the Twentieth Century, Michael D. Bordo, Claudia Goldin and Eugene N. White (eds.), Chicago: University of Chicago Press, pp. 353 - 402.

Obstfeld, Maurice, Jay Shambaugh and Alan M. Taylor. (2004). "Monetary Sovereignty, Exchange Rates and Capital Controls: The Trilemma in the Interwar Period," IMF Staff Papers 51 (special issue).

Ostry, Jonathan, Atish Ghosh, Karl Habermeier, Marcos Chamon, Mahvash Qureshi and Dennis Reinhardt. (2010). "Capital Inflows: The Role of Controls" IMF Staff Position Papers 10/04.

Ritschl, Albrecht und Nikolaus Wolf. (2003). "Endogeneity of Currency Areas and Trade Blocs: Evidence from the Inter-war Period.” CEPR Discussion Paper 4112.

Romer, Christina. (1992). "What Ended the Great Depression?" Journal of Economic History 52: 757-784.

Schmitt-Grohe, Stephanie and Martin Uribe. (2012). "Prudential Policy for Peggers," NBER Working Paper 18031.

Statistisches Reichsamt. (1934). Statistisches Handbuch der Weltwirtschaft. Berlin: Verlag für Sozialpolitik, Wirtschaft und Statistik Paul Schmidt. 
Statistisches Reichsamt. (1936-7). Statistisches Handbuch der Weltwirtschaft. Berlin: Verlag für Sozialpolitik, Wirtschaft und Statistik Paul Schmidt.

Simmons, Beth. (1997). Who Adjusts? Domestic Sources of Foreign Economic Policy During the Interwar Years. Princeton, NJ: Princeton University Press.

Temin, Peter. (1989). Lessons from the Great Depression. Cambridge, MA: MIT Press.

Thorp, Rosemary. (1984). Latin America in the 1930s. London: Macmillan.

United States Tariff Commission (1942). Foreign-Trade and Exchange Controls in Germany, Report No. 150, Second Series, Washington D.C.

Wandschneider, Kirsten (2008). “The Stability of the Interwar Gold Exchange Standard: Did Politics Matter?” Journal of Economic History 68(1): 151-181.

Wei, Shang-Jin \& Zhang, Zhiwei (2007). “Collateral Damage: Exchange Controls and International Trade.” Journal of International Money and Finance 26(5): 841-63.

Wolf, Nikolaus (2008). "Scylla and Charybdis. Explaining Europe's Exit from Gold." Explorations in Economic History 45(4): 383-401. 
Table 1: Classifications of Exchange Rate Regimes

\begin{tabular}{|l|l|l|l|}
\hline \multicolumn{4}{|l|}{ Panel A: Exchange control countries } \\
\hline Country & $\begin{array}{l}\text { Official } \\
\text { Suspension }\end{array}$ & $\begin{array}{l}\text { Exchange } \\
\text { Control }\end{array}$ & $\begin{array}{l}\text { Devaluation } \\
\text { or } \\
\text { depreciation }\end{array}$ \\
\hline Argentina & $12 / 29$ & $10 / 31$ & $11 / 29$ \\
\hline Austria & $4 / 33$ & $10 / 31$ & $9 / 31 ; 4 / 34$ \\
\hline Bolivia & $9 / 31$ & $10 / 31$ & $3 / 30$ \\
\hline Brazil & & $5 / 31$ & $12 / 29$ \\
\hline Bulgaria & & 1918 & \\
\hline Chile & $4 / 32$ & $7 / 31$ & $4 / 32$ \\
\hline China & & $9 / 34$ & \\
\hline Colombia & $9 / 31$ & $9 / 31$ & $1 / 32$ \\
\hline Costa Rica & & $1 / 32$ & \\
\hline Cuba** & $11 / 33$ & $6 / 34-7 / 34$ & $4 / 33$ \\
\hline Czechoslovakia & & $10 / 31$ & $2 / 34 ; 10 / 36$ \\
\hline Denmark & $9 / 31$ & $11 / 31$ & $9 / 31$ \\
\hline Ecuador & $2 / 32$ & $5 / 32-10 / 35 ;$ & $6 / 32$ \\
\hline El Salvador** & $10 / 31$ & $7 / 36$ & \\
\hline Estonia & $6 / 33$ & $11 / 31$ & $6 / 31$ \\
\hline Germany & & $7 / 31$ & \\
\hline Greece & $4 / 32$ & $9 / 31$ & $4 / 32$ \\
\hline Hungary & & $7 / 31$ & \\
\hline Iran & & $2 / 30-5 / 33 ;$ & \\
\hline Italy & & $3 / 36$ & $10 / 31$ \\
\hline Japan & $12 / 31$ & $7 / 32$ & $3 / 34 ; 10 / 36$ \\
\hline Latvia & $9 / 36$ & $10 / 31$ & $12 / 31$ \\
\hline Nicaragua** & $11 / 31$ & $11 / 31$ & $1 / 32$ \\
\hline Romania & & $5 / 32$ & $7 / 35$ \\
\hline Turkey & & $2 / 30$ & \\
\hline Uruguay & $7 / 29$ & $9 / 31$ & $4 / 29$ \\
\hline Venezuela & & $12 / 36$ & $9 / 30$ \\
\hline Yugoslavia & & $10 / 31$ & $7 / 32$ \\
\hline & & & \\
\hline & & \\
\hline
\end{tabular}


Table 1: Classifications of Exchange Rate Regimes (continued)

\begin{tabular}{|l|l|l|l|}
\hline Panel B: Free Currency - Floaters \\
\hline Country & $\begin{array}{l}\text { Official } \\
\text { Suspension } \\
\text { Control }\end{array}$ & $\begin{array}{l}\text { Devaluation } \\
\text { or } \\
\text { depreciation }\end{array}$ \\
\hline Australia & $12 / 29$ & & $3 / 30$ \\
\hline Canada & $10 / 31$ & & $9 / 31$ \\
\hline Egypt & $9 / 31$ & & \\
\hline Finland & $10 / 31$ & $10 / 31-12 / 31$ & $10 / 31$ \\
\hline Guatemala** & & & $4 / 33$ \\
\hline India & $9 / 31$ & & $9 / 31$ \\
\hline Iraq** & & & \\
\hline Irish Free State & $9 / 31$ & & $9 / 31$ \\
\hline Mexico & $7 / 31$ & & $8 / 31$ \\
\hline New Zealand & $9 / 31$ & & $4 / 30$ \\
\hline Norway & $9 / 31$ & & $9 / 31$ \\
\hline Peru & $5 / 32$ & & $5 / 32$ \\
\hline Philippines** & & & $4 / 33$ \\
\hline Portugal & $12 / 31$ & $10 / 22$ & $10 / 31$ \\
\hline South Africa & $12 / 32$ & & $1 / 33$ \\
\hline Sweden & $9 / 31$ & & $9 / 31$ \\
\hline UK & $9 / 31$ & & $9 / 31$ \\
\hline US & $4 / 33$ & $3 / 33-11 / 34$ & $4 / 33$ \\
\hline & & & \\
\hline
\end{tabular}

\begin{tabular}{|l|l|l|l|}
\hline Panel C: Countries on Gold after 1934 \\
\hline Country & $\begin{array}{l}\text { Official } \\
\text { Suspension } \\
\text { Control }\end{array}$ & $\begin{array}{l}\text { Exchange } \\
\text { or } \\
\text { depreciation }\end{array}$ \\
\hline Albania & & & \\
\hline Belgium & $3 / 35$ & $3 / 35-4 / 35$ & $3 / 35$ \\
\hline France & & & $9 / 36$ \\
\hline Hong-Kong** & & $11 / 35$ & \\
\hline Lithuania & & $10 / 35$ & \\
\hline Netherlands & $9 / 36$ & & $9 / 36$ \\
\hline $\begin{array}{l}\text { Netherlands } \\
\text { Indies }\end{array}$ & $9 / 36$ & & $9 / 36$ \\
\hline Poland & & $4 / 36$ & \\
\hline Switzerland & & & $9 / 36$ \\
\hline
\end{tabular}


Table 1: Classifications of Exchange Rate Regimes (continued)

\begin{tabular}{|l|l|l|l|}
\hline Panel D: Others & $\begin{array}{l}\text { Official } \\
\text { Suspension }\end{array}$ & $\begin{array}{l}\text { Exchange } \\
\text { Control }\end{array}$ & $\begin{array}{l}\text { Devaluation } \\
\text { or } \\
\text { depreciation }\end{array}$ \\
\hline Spain* & & $5 / 31$ & \\
\hline USSR* & & & $4 / 36$ \\
\hline
\end{tabular}

Source: League of Nations (1937), BIS (1936). Data on clearing agreements only extends to 1935.

*USSR and Spain were dropped from the econometric analysis since they were not on the gold standard prior to floating or imposing exchange controls.

** These countries have exchange rate data, but no corresponding monthly observations for industrial production, wholesale prices, and exports. Hence, they are excluded from the econometric analysis. 
Table 2: The Effects of Capital Controls on Prices, Exports and Production

\begin{tabular}{|l|l|l|l|c|l|l|l|l|}
\hline & \multicolumn{3}{|c|}{ Cross Section, 1929-1935 } & \multicolumn{4}{c|}{ Cross Section 1929-1936 } \\
\hline $\begin{array}{l}\text { Dependent } \\
\text { Variable }\end{array}$ & Constant & $\begin{array}{l}\text { Capital } \\
\text { Control } \\
\text { Dummy }\end{array}$ & $\begin{array}{l}\text { Gold } \\
\text { Bloc } \\
\text { Dummy }\end{array}$ & R2 & Constant & $\begin{array}{l}\text { Capital } \\
\text { Control } \\
\text { Dummy }\end{array}$ & $\begin{array}{l}\text { Gold } \\
\text { Bloc } \\
\text { Dummy }\end{array}$ & R2 \\
\hline Industrial & -10.73 & 9.62 & $-18.68^{*}$ & 0.3 & -2.98 & 10.40 & $-24.08^{*}$ & 0.36 \\
Production & $(7.63)$ & $(9.23)$ & $(10.79)$ & & $(8.17)$ & $(10.01)$ & $(11.56)$ & \\
Wholesale & $-15.14 * *$ & -5.31 & $-28.15^{* *}$ & 0.45 & $-14.04 * *$ & -3.47 & $-24.33^{* *}$ & 0.37 \\
Prices & $(3.10)$ & $(4.46)$ & $(5.50)$ & & $(3.24)$ & $(4.43)$ & $(5.61)$ & \\
Exports & $-23.29 * *$ & -16.58 & $-38.72 * *$ & 0.19 & -14.19 & $-20.28^{*}$ & $-42.19^{* *}$ & 0.2 \\
& $(7.93)$ & $(10.86)$ & $(13.74)$ & & $(8.14)$ & $(11.53)$ & $(14.58)$ & \\
\hline
\end{tabular}

Notes: Standard errors are shown in parentheses. * indicates significance at the $10 \%$ level and ** indicates significance at $5 \%$ level. 
Table 3: Difference-in-Differences Estimates of the Effects of Capital Controls on Wholesale Prices, Exports, and Industrial Production

\begin{tabular}{|c|c|c|c|c|c|c|c|c|c|}
\hline & \multicolumn{9}{|c|}{ Dependent Variable } \\
\hline $\begin{array}{l}\text { Independent } \\
\text { Variable }\end{array}$ & $\begin{array}{l}\text { Monthly } \\
\text { Change } \\
\text { in IP }\end{array}$ & $\begin{array}{l}\text { Monthly } \\
\text { Change } \\
\text { in WPI }\end{array}$ & $\begin{array}{l}\text { Monthly } \\
\text { Change } \\
\text { in EXP }\end{array}$ & $\begin{array}{l}\text { Monthly } \\
\text { Change } \\
\text { in IP }\end{array}$ & $\begin{array}{l}\text { Monthly } \\
\text { Chage in } \\
\text { WPI }\end{array}$ & $\begin{array}{l}\text { Monthly } \\
\text { Change } \\
\text { in EXP }\end{array}$ & $\begin{array}{l}\text { Monthly } \\
\text { Change } \\
\text { in IP }\end{array}$ & $\begin{array}{l}\text { Monthly } \\
\text { Change } \\
\text { in WPI }\end{array}$ & $\begin{array}{l}\text { Monthly } \\
\text { Change } \\
\text { in EXP }\end{array}$ \\
\hline Constant & $\begin{array}{l}-0.0151 \\
(0.013)\end{array}$ & $\begin{array}{l}-0.0054 \\
(0.004)\end{array}$ & $\begin{array}{l}0.0644 \\
(0.035)\end{array}$ & $\begin{array}{l}0.0082 \\
(0.024)\end{array}$ & $\begin{array}{l}-0.0173^{*} \\
(0.010)\end{array}$ & $\begin{array}{l}-0.142 * * \\
(0.029)\end{array}$ & $\begin{array}{l}-0.0098 \\
(0.020)\end{array}$ & $\begin{array}{l}-0.033^{* *} \\
(0.008)\end{array}$ & $\begin{array}{l}-0.109 * * \\
(0.040)\end{array}$ \\
\hline OffGold & $\begin{array}{l}0.011^{* *} \\
(0.005)\end{array}$ & $\begin{array}{l}0.0073 * * \\
(0.002)\end{array}$ & $\begin{array}{l}0.0178^{* *} \\
(0.005)\end{array}$ & $\begin{array}{l}0.0122 * * \\
(0.005)\end{array}$ & $\begin{array}{l}0.0079 * * \\
(0.002)\end{array}$ & $\begin{array}{l}0.0154 * * \\
(0.005)\end{array}$ & $\begin{array}{l}0.017 * * \\
(0.007)\end{array}$ & $\begin{array}{l}0.0096^{* * *} \\
(0.003)\end{array}$ & $\begin{array}{l}0.0234 * * \\
(0.005)\end{array}$ \\
\hline $\begin{array}{l}\text { OffGold* } \\
\text { Xcontrol }\end{array}$ & $\begin{array}{l}-0.007 * \\
(0.003)\end{array}$ & $\begin{array}{l}-0.0017 \\
(0.002)\end{array}$ & $\begin{array}{l}-0.0052 \\
(0.004)\end{array}$ & $\begin{array}{l}-0.008^{* *} \\
(0.004)\end{array}$ & $\begin{array}{l}-0.0025 \\
(0.002)\end{array}$ & $\begin{array}{l}-0.0034 \\
(0.004)\end{array}$ & $\begin{array}{l}-0.007 \\
(0.005)\end{array}$ & $\begin{array}{l}-0.0012 \\
(0.004)\end{array}$ & $\begin{array}{l}-0.0036 \\
(0.007)\end{array}$ \\
\hline $\begin{array}{l}\text { OffGold* } \\
\text { Stalwart }\end{array}$ & $\begin{array}{l}0.0015 \\
(0.006)\end{array}$ & $\begin{array}{l}0.013 * \\
(0.007)\end{array}$ & $\begin{array}{l}0.0030 \\
(0.010)\end{array}$ & $\begin{array}{l}0.0008 \\
(0.006)\end{array}$ & $\begin{array}{l}0.0122 * \\
(0.006)\end{array}$ & $\begin{array}{l}0.0001 \\
(0.010)\end{array}$ & $\begin{array}{l}0.0071 \\
(0.010)\end{array}$ & $\begin{array}{l}0.0119 \\
(0.008)\end{array}$ & $\begin{array}{l}0.0076 \\
(0.011)\end{array}$ \\
\hline $\begin{array}{l}\text { Time Fixed } \\
\text { Effects }\end{array}$ & yes & yes & yes & yes & yes & yes & yes & yes & yes \\
\hline $\begin{array}{l}\text { Country } \\
\text { Fixed Effects }\end{array}$ & yes & yes & yes & yes & yes & yes & yes & yes & yes \\
\hline $\begin{array}{l}\text { Lagged } \\
\text { Discount } \\
\text { Rate }\end{array}$ & no & no & no & yes & yes & yes & yes & yes & yes \\
\hline $\begin{array}{l}\text { Trade } \\
\text { Barriers }\end{array}$ & No & no & no & no & no & no & yes & yes & yes \\
\hline R squared & 0.14 & 0.2 & 0.16 & 0.14 & 0.2 & 0.16 & 0.13 & 0.27 & 0.17 \\
\hline Observations & 3343 & 3778 & 5124 & 3221 & 3463 & 4716 & 1756 & 1908 & 2560 \\
\hline Countries & 25 & 37 & 36 & 25 & 32 & 34 & 14 & 17 & 19 \\
\hline
\end{tabular}

Notes: The table displays regression estimates of equation (1) from the text. Variable are described in the text.

Standard errors are shown in parentheses and are clustered at the country level. * indicates significance at the $10 \%$ level and $* *$ indicates significance at the $5 \%$ level. All equations include time and country fixed effects. 
Table 4. Additional Specifications Assessing the Effects of Capital Controls

\begin{tabular}{|c|c|c|c|c|c|c|}
\hline & \multicolumn{3}{|c|}{ Alternative Fixed Effects Estimates } & \multicolumn{3}{|c|}{ Instrumental Variables Estimates } \\
\hline & \multicolumn{3}{|c|}{ Dependent Variable } & \multicolumn{3}{|c|}{ Dependent Variable } \\
\hline $\begin{array}{l}\text { Independent } \\
\text { Variable }\end{array}$ & $\begin{array}{l}\text { Monthly } \\
\text { Change } \\
\text { in IP }\end{array}$ & $\begin{array}{c}\text { Monthly } \\
\text { Change } \\
\text { in } \\
\text { WPI }\end{array}$ & $\begin{array}{l}\text { Monthly } \\
\text { Change } \\
\text { in EXP }\end{array}$ & $\begin{array}{l}\text { Monthly } \\
\text { Change } \\
\text { in IP }\end{array}$ & $\begin{array}{l}\text { Monthly } \\
\text { Change } \\
\text { in WPI }\end{array}$ & $\begin{array}{c}\text { Monthly } \\
\text { Change in } \\
\text { EXP }\end{array}$ \\
\hline Xcontrol & & & & $\begin{array}{l}-0.0012 \\
(0.0030)\end{array}$ & $\begin{array}{l}-0.0012 \\
(0.0020)\end{array}$ & $\begin{array}{l}0.0100 * * * \\
(0.0034)\end{array}$ \\
\hline Stalwart & & & & $\begin{array}{l}-0.0005 \\
(0.0033)\end{array}$ & $\begin{array}{l}0.0001 \\
(0.0018)\end{array}$ & $\begin{array}{l}0.0061 \\
(0.0039)\end{array}$ \\
\hline Off Gold & $\begin{array}{l}0.0097 * * * \\
(0.0032)\end{array}$ & $\begin{array}{l}0.0105 * * * \\
(0.0013)\end{array}$ & $\begin{array}{l}0.0138 * * * \\
(0.0030) \\
\end{array}$ & $\begin{array}{l}0.0047 \\
(0.0064)\end{array}$ & $\begin{array}{l}0.0057 * * * \\
(0.0021)\end{array}$ & $\begin{array}{l}0.0206 * * * \\
(0.0065)\end{array}$ \\
\hline $\begin{array}{l}\text { OffGold* } \\
\text { Xcontrol } \\
\end{array}$ & $\begin{array}{l}-0.0066^{* *} \\
(0.0034) \\
\end{array}$ & $\begin{array}{l}-0.0031 \\
(0.0021) \\
\end{array}$ & $\begin{array}{l}-0.0031 \\
(0.0042) \\
\end{array}$ & $\begin{array}{l}0.0036 \\
(0.0062)\end{array}$ & $\begin{array}{l}-0.0019 \\
(0.0030) \\
\end{array}$ & $\begin{array}{l}-0.0186^{* * * *} \\
(0.0058)\end{array}$ \\
\hline $\begin{array}{l}\text { OffGold* } \\
\text { Stalwart } \\
\end{array}$ & $\begin{array}{l}0.0090 \\
(0.0071) \\
\end{array}$ & $\begin{array}{l}0.0177^{*} \\
(0.0082) \\
\end{array}$ & $\begin{array}{l}0.0350 * * * \\
(0.0111)\end{array}$ & $\begin{array}{l}0.0099 \\
(0.0090) \\
\end{array}$ & $\begin{array}{l}0.0204 * * \\
(0.0095)\end{array}$ & $\begin{array}{l}-0.0070 \\
(0.0160) \\
\end{array}$ \\
\hline $\begin{array}{l}\text { Time } \\
\text { Dummies }\end{array}$ & no & no & no & yes & yes & yes \\
\hline $\begin{array}{l}\text { Country } \\
\text { Dummies }\end{array}$ & yes & yes & yes & no & no & no \\
\hline Observations & 3343 & 3778 & 5124 & 3057 & 3123 & 4123 \\
\hline Countries & 25 & 37 & 36 & 23 & 28 & 29 \\
\hline
\end{tabular}


Table 5: Explaining the Movement of Discount Rates for Capital Control Countries, 19251936

Panel A: Individual Countries

\begin{tabular}{|c|c|c|c|c|c|}
\hline $\begin{array}{l}\text { Country } \\
\text { Imposing } \\
\text { Capital } \\
\text { Controls }\end{array}$ & $\begin{array}{l}\text { Independent } \\
\text { Variable }\end{array}$ & $\begin{array}{l}\text { United } \\
\text { States }\end{array}$ & France & England & Germany \\
\hline \multirow[t]{3}{*}{ Austria } & XControl & $\begin{array}{l}-0.069 \\
(0.08)\end{array}$ & $\begin{array}{l}-0.084 \\
(0.08)\end{array}$ & $\begin{array}{l}-0.033 \\
(0.07)\end{array}$ & $\begin{array}{l}-0.071 \\
(0.07)\end{array}$ \\
\hline & Base & $\begin{array}{l}0.178 \\
(0.13) \\
\end{array}$ & $\begin{array}{l}0.287 \\
(0.15) \\
\end{array}$ & $\begin{array}{l}0.563 * \\
(0.24)\end{array}$ & $\begin{array}{l}0.607 * * * \\
(0.16)\end{array}$ \\
\hline & XControl*Base & $\begin{array}{l}-0.331 \\
(0.21)\end{array}$ & $\begin{array}{l}-0.267 \\
(0.16)\end{array}$ & $\begin{array}{l}-0.273 \\
(0.33)\end{array}$ & $\begin{array}{l}-0.451 \\
(0.28)\end{array}$ \\
\hline \multirow[t]{3}{*}{ Czechoslovakia } & XControl & $\begin{array}{l}-0.064 \\
(0.04) \\
\end{array}$ & $\begin{array}{l}-0.064 \\
(0.04)\end{array}$ & $\begin{array}{l}-0.052 \\
(0.04)\end{array}$ & $\begin{array}{l}-0.030 \\
(0.03) \\
\end{array}$ \\
\hline & Base & $\begin{array}{l}0.113 \\
(0.11) \\
\end{array}$ & $\begin{array}{l}0.039 \\
(0.04) \\
\end{array}$ & $\begin{array}{l}0.222 \\
(0.17) \\
\end{array}$ & $\begin{array}{l}-0.072 \\
(0.11) \\
\end{array}$ \\
\hline & XControl*Base & $\begin{array}{l}-0.113 \\
(0.11) \\
\end{array}$ & $\begin{array}{l}-0.020 \\
(0.04) \\
\end{array}$ & $\begin{array}{l}-0.148 \\
(0.21) \\
\end{array}$ & $\begin{array}{l}0.547 * * \\
(0.21)\end{array}$ \\
\hline \multirow[t]{3}{*}{ Estonia } & XControl & $\begin{array}{l}0.003 \\
(0.04) \\
\end{array}$ & $\begin{array}{l}0.006 \\
(0.04) \\
\end{array}$ & $\begin{array}{l}0.012 \\
(0.03) \\
\end{array}$ & $\begin{array}{l}-0.004 \\
(0.04)\end{array}$ \\
\hline & Base & $\begin{array}{l}-0.007 \\
(0.01) \\
\end{array}$ & $\begin{array}{l}-0.126 \\
(0.14) \\
\end{array}$ & $\begin{array}{l}-0.070 \\
(0.05) \\
\end{array}$ & $\begin{array}{l}-0.002 \\
(0.05) \\
\end{array}$ \\
\hline & XControl*Base & $\begin{array}{l}0.085 \\
(0.08) \\
\end{array}$ & $\begin{array}{l}0.126 \\
(0.14) \\
\end{array}$ & $\begin{array}{l}0.303 \\
(0.25) \\
\end{array}$ & $\begin{array}{l}-0.032 \\
(0.05) \\
\end{array}$ \\
\hline \multirow[t]{3}{*}{ Germany } & XControl & $\begin{array}{l}-0.010 \\
(0.08) \\
\end{array}$ & $\begin{array}{l}-0.002 \\
(0.08) \\
\end{array}$ & $\begin{array}{r}-0.001 \\
(0.06) \\
\end{array}$ & \\
\hline & Base & $\begin{array}{l}0.177 \\
(0.11) \\
\end{array}$ & $\begin{array}{l}-0.062 \\
(0.10)\end{array}$ & $\begin{array}{l}0.320 \\
(0.45) \\
\end{array}$ & \\
\hline & XControl*Base & $\begin{array}{l}-0.177 \\
(0.11) \\
\end{array}$ & $\begin{array}{l}0.062 \\
(0.10) \\
\end{array}$ & $\begin{array}{l}0.146 \\
(0.46) \\
\end{array}$ & \\
\hline \multirow[t]{3}{*}{ Greece } & XControl & $\begin{array}{l}-0.050 \\
(0.07) \\
\end{array}$ & $\begin{array}{l}-0.064 \\
(0.07)\end{array}$ & $\begin{array}{r}-0.041 \\
(0.07) \\
\end{array}$ & $\begin{array}{l}-0.063 \\
(0.07) \\
\end{array}$ \\
\hline & Base & $\begin{array}{l}0.004 \\
(0.01)\end{array}$ & $\begin{array}{l}0.222 \\
(0.15)\end{array}$ & $\begin{array}{l}0.280 \\
(0.31)\end{array}$ & $\begin{array}{l}-0.312 \\
(0.21)\end{array}$ \\
\hline & XControl*Base & $\begin{array}{l}-0.197 \\
(0.21) \\
\end{array}$ & $\begin{array}{l}-0.232 \\
(0.15) \\
\end{array}$ & $\begin{array}{r}-0.053 \\
(0.37) \\
\end{array}$ & $\begin{array}{l}0.269 \\
(0.25) \\
\end{array}$ \\
\hline \multirow[t]{3}{*}{ Hungary } & XControl & $\begin{array}{l}0.026 \\
(0.07) \\
\end{array}$ & $\begin{array}{l}0.025 \\
(0.07) \\
\end{array}$ & $\begin{array}{l}0.012 \\
(0.06) \\
\end{array}$ & $\begin{array}{l}0.013 \\
(0.06) \\
\end{array}$ \\
\hline & Base & $\begin{array}{l}0.021 \\
(0.17)\end{array}$ & $\begin{array}{l}0.020 \\
(0.06)\end{array}$ & $\begin{array}{l}0.247 \\
(0.31)\end{array}$ & $\begin{array}{l}0.478 * * * \\
(0.10)\end{array}$ \\
\hline & XControl*Base & $\begin{array}{l}-0.021 \\
(0.17)\end{array}$ & $\begin{array}{l}-0.015 \\
(0.06)\end{array}$ & $\begin{array}{r}-0.177 \\
(0.33)\end{array}$ & $\begin{array}{l}-0.267 \\
(0.24)\end{array}$ \\
\hline
\end{tabular}




\begin{tabular}{|c|c|c|c|c|c|}
\hline \multirow[t]{3}{*}{ Italy } & XControl & $\begin{array}{l}0.068 \\
(0.06)\end{array}$ & $\begin{array}{l}0.068 \\
(0.06)\end{array}$ & $\begin{array}{l}0.056 \\
(0.06)\end{array}$ & $\begin{array}{l}0.063 \\
(0.06)\end{array}$ \\
\hline & Base & $\begin{array}{l}0.106 \\
(0.07)\end{array}$ & $\begin{array}{l}0.019 \\
(0.04)\end{array}$ & $\begin{array}{l}0.261 \\
(0.15)\end{array}$ & $\begin{array}{l}-0.092 \\
(0.11)\end{array}$ \\
\hline & XControl*Base & $\begin{array}{l}-0.106 \\
(0.07)\end{array}$ & $\begin{array}{l}-0.037 \\
(0.04)\end{array}$ & $\begin{array}{l}0.230 \\
(0.24)\end{array}$ & $\begin{array}{l}0.326 \\
(0.25)\end{array}$ \\
\hline \multirow[t]{3}{*}{ Latvia } & XControl & $\begin{array}{l}0.009 \\
(0.02)\end{array}$ & $\begin{array}{l}0.010 \\
(0.02)\end{array}$ & $\begin{array}{l}0.008 \\
(0.02)\end{array}$ & $\begin{array}{l}0.007 \\
(0.02)\end{array}$ \\
\hline & Base & $\begin{array}{l}-0.006 \\
(0.01)\end{array}$ & $\begin{array}{l}-0.017 \\
(0.02)\end{array}$ & $\begin{array}{l}0.004 \\
(0.01)\end{array}$ & $\begin{array}{l}0.035 \\
(0.04)\end{array}$ \\
\hline & XControl*Base & $\begin{array}{l}0.006 \\
(0.01)\end{array}$ & $\begin{array}{l}0.017 \\
(0.02)\end{array}$ & $\begin{array}{c}-0.021 \\
(0.01)\end{array}$ & $\begin{array}{l}-0.052 \\
(0.04)\end{array}$ \\
\hline \multirow[t]{3}{*}{ Romania } & XControl & $\begin{array}{l}-0.055 \\
(0.05)\end{array}$ & $\begin{array}{l}-0.057 \\
(0.06)\end{array}$ & $\begin{array}{l}-0.062 \\
(0.05)\end{array}$ & $\begin{array}{l}-0.061 \\
(0.05)\end{array}$ \\
\hline & Base & $\begin{array}{l}0.114 \\
(0.08)\end{array}$ & $\begin{array}{l}0.008 \\
(0.03)\end{array}$ & $\begin{array}{l}0.015 \\
(0.02)\end{array}$ & $\begin{array}{l}0.011 \\
(0.01)\end{array}$ \\
\hline & XControl*Base & $\begin{array}{l}-0.050 \\
(0.12)\end{array}$ & $\begin{array}{l}-0.009 \\
(0.03)\end{array}$ & $\begin{array}{l}0.369 \\
(0.21)\end{array}$ & $\begin{array}{l}0.245 \\
(0.23)\end{array}$ \\
\hline \multirow[t]{3}{*}{ Argentina } & XControl & $\begin{array}{l}-0.053 \\
(0.04)\end{array}$ & $\begin{array}{l}-0.054 \\
(0.03)\end{array}$ & $\begin{array}{r}-0.058 \\
(0.04)\end{array}$ & $\begin{array}{l}-0.057 \\
(0.04)\end{array}$ \\
\hline & Base & $\begin{array}{l}-0.036 \\
(0.04)\end{array}$ & $\begin{array}{l}0.004 \\
(0.01)\end{array}$ & $\begin{array}{l}-0.038 \\
(0.03)\end{array}$ & $\begin{array}{l}0.000 \\
(0.00)\end{array}$ \\
\hline & XControl*Base & $\begin{array}{l}-0.118 \\
(0.17)\end{array}$ & $\begin{array}{l}-0.142 \\
(0.11)\end{array}$ & $\begin{array}{r}-0.013 \\
(0.05)\end{array}$ & $\begin{array}{l}-0.051 \\
(0.04)\end{array}$ \\
\hline \multirow[t]{3}{*}{ Chile } & XControl & $\begin{array}{l}-0.070 \\
(0.05)\end{array}$ & $\begin{array}{l}-0.082 \\
(0.05) \\
\end{array}$ & $\begin{array}{r}-0.052 \\
(0.05)\end{array}$ & $\begin{array}{l}-0.082 \\
(0.05) \\
\end{array}$ \\
\hline & Base & $\begin{array}{l}-0.156 \\
(0.16)\end{array}$ & $\begin{array}{l}0.090 \\
(0.08)\end{array}$ & $\begin{array}{l}-0.211 \\
(0.15)\end{array}$ & $\begin{array}{l}0.082 \\
(0.07)\end{array}$ \\
\hline & XControl*Base & $\begin{array}{l}-0.113 \\
(0.22)\end{array}$ & $\begin{array}{l}-0.119 \\
(0.09)\end{array}$ & $\begin{array}{l}0.292 \\
(0.20)\end{array}$ & $\begin{array}{l}-0.147 \\
(0.09)\end{array}$ \\
\hline \multirow[t]{3}{*}{ Colombia } & XControl & $\begin{array}{l}-0.041 \\
(0.04)\end{array}$ & $\begin{array}{l}-0.051 \\
(0.04)\end{array}$ & $\begin{array}{r}-0.049 \\
(0.04)\end{array}$ & $\begin{array}{l}-0.033 \\
(0.04)\end{array}$ \\
\hline & Base & $\begin{array}{l}-0.298 \\
(0.19)\end{array}$ & $\begin{array}{l}0.070 \\
(0.07)\end{array}$ & $\begin{array}{r}-0.032 \\
(0.07)\end{array}$ & $\begin{array}{l}-0.002 \\
(0.03)\end{array}$ \\
\hline & XControl*Base & $\begin{array}{l}0.298 \\
(0.19)\end{array}$ & $\begin{array}{l}-0.070 \\
(0.07)\end{array}$ & $\begin{array}{c}-0.018 \\
(0.08)\end{array}$ & $\begin{array}{l}0.219 \\
(0.22)\end{array}$ \\
\hline \multirow[t]{3}{*}{ Japan } & XControl & $\begin{array}{l}-0.008 \\
(0.03)\end{array}$ & $\begin{array}{l}-0.019 \\
(0.03)\end{array}$ & $\begin{array}{l}-0.026 \\
(0.03)\end{array}$ & $\begin{array}{l}-0.022 \\
(0.03)\end{array}$ \\
\hline & Base & $\begin{array}{l}-0.007 \\
(0.01)\end{array}$ & $\begin{array}{l}-0.017 \\
(0.02)\end{array}$ & $\begin{array}{l}0.002 \\
(0.00)\end{array}$ & $\begin{array}{l}-0.028 \\
(0.02)\end{array}$ \\
\hline & XControl*Base & $\begin{array}{l}0.286^{* *} \\
(0.09)\end{array}$ & $\begin{array}{l}0.024 \\
(0.02)\end{array}$ & $\begin{array}{l}0.343^{*} \\
(0.14)\end{array}$ & $\begin{array}{l}0.185 \\
(0.16)\end{array}$ \\
\hline Observations & & 143 & 143 & 143 & 143 \\
\hline
\end{tabular}


Table 5: Explaining the Movement of Discount Rates for Capital Control Countries, 19251936

\section{Panel B: Pooled Regressions}

\begin{tabular}{|l|l|l|l|}
\hline $\begin{array}{l}\text { Independent } \\
\text { Variable }\end{array}$ & United States & France & England \\
\hline $\begin{array}{l}\text { Capital } \\
\text { Control } \\
\text { Indicator }\end{array}$ & $\begin{array}{l}-0.033^{* * *} \\
(0.010)\end{array}$ & $\begin{array}{l}-0.035^{* * *} \\
(0.011)\end{array}$ & $\begin{array}{r}-0.021^{*} \\
(0.012)\end{array}$ \\
\hline $\begin{array}{l}\text { Base } \\
\text { Country } \\
\text { Discount } \\
\text { Rate }\end{array}$ & 0.019 & $0.0407^{*}$ & $0.080^{*}$ \\
$(0.027)$ & $(0.022)$ & $(0.041)$ \\
\hline $\begin{array}{l}\text { Interaction } \\
\text { Term }\end{array}$ & $-0.058^{*}$ & $-0.049^{* *}$ & $0.195^{*}$ \\
\hline & $(0.033)$ & $(0.022)$ & $(0.102)$ \\
\hline Observations & 2334 & & \\
\hline Countries & 17 & 2334 & 2334 \\
\hline
\end{tabular}


Figure 1: Average Cover Ratios for Exchange Control Countries

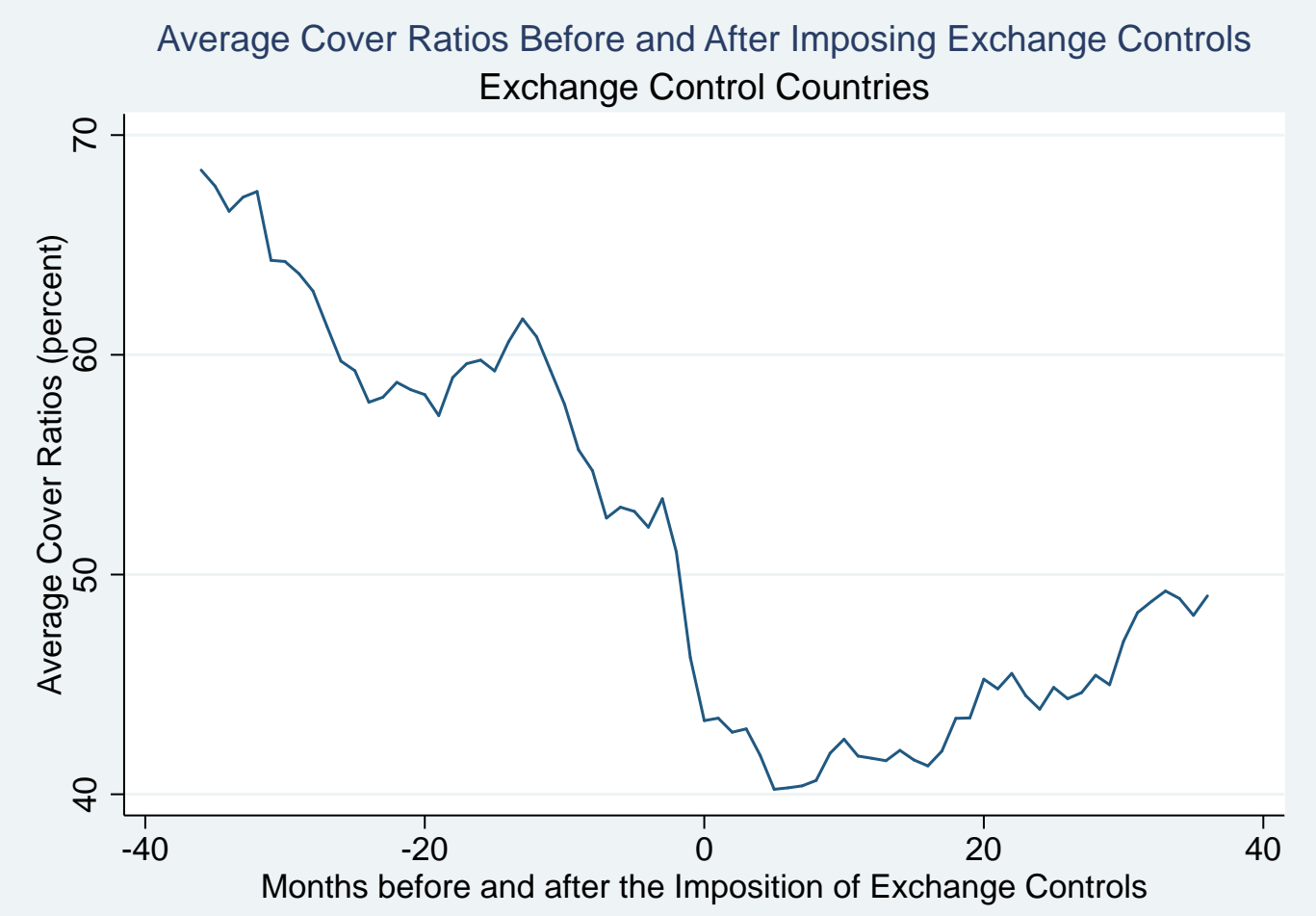

Note: The cover ratio is calculated as the ratio of bank gold reserves and foreign assets to domestic liabilities. Source: Statistisches Handbuch der Weltwirtschaft $(1934,1936 / 7)$. 
Figure 2: Exchange Rates and Industrial Production, 1929-36

(1929=100)

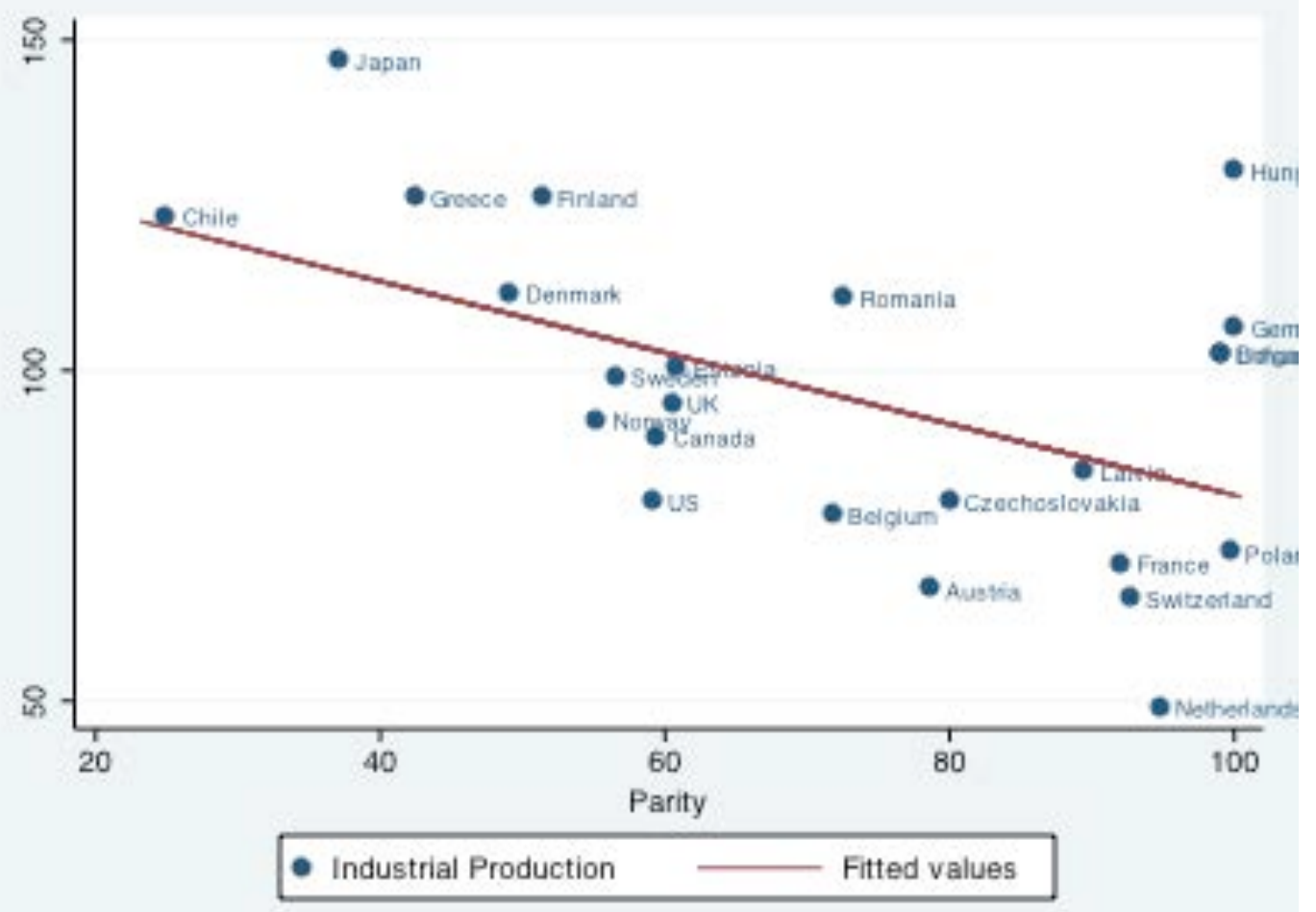

Figure 3: Exchange Rates and Wholesale Prices, 1929-36

(1929=100)

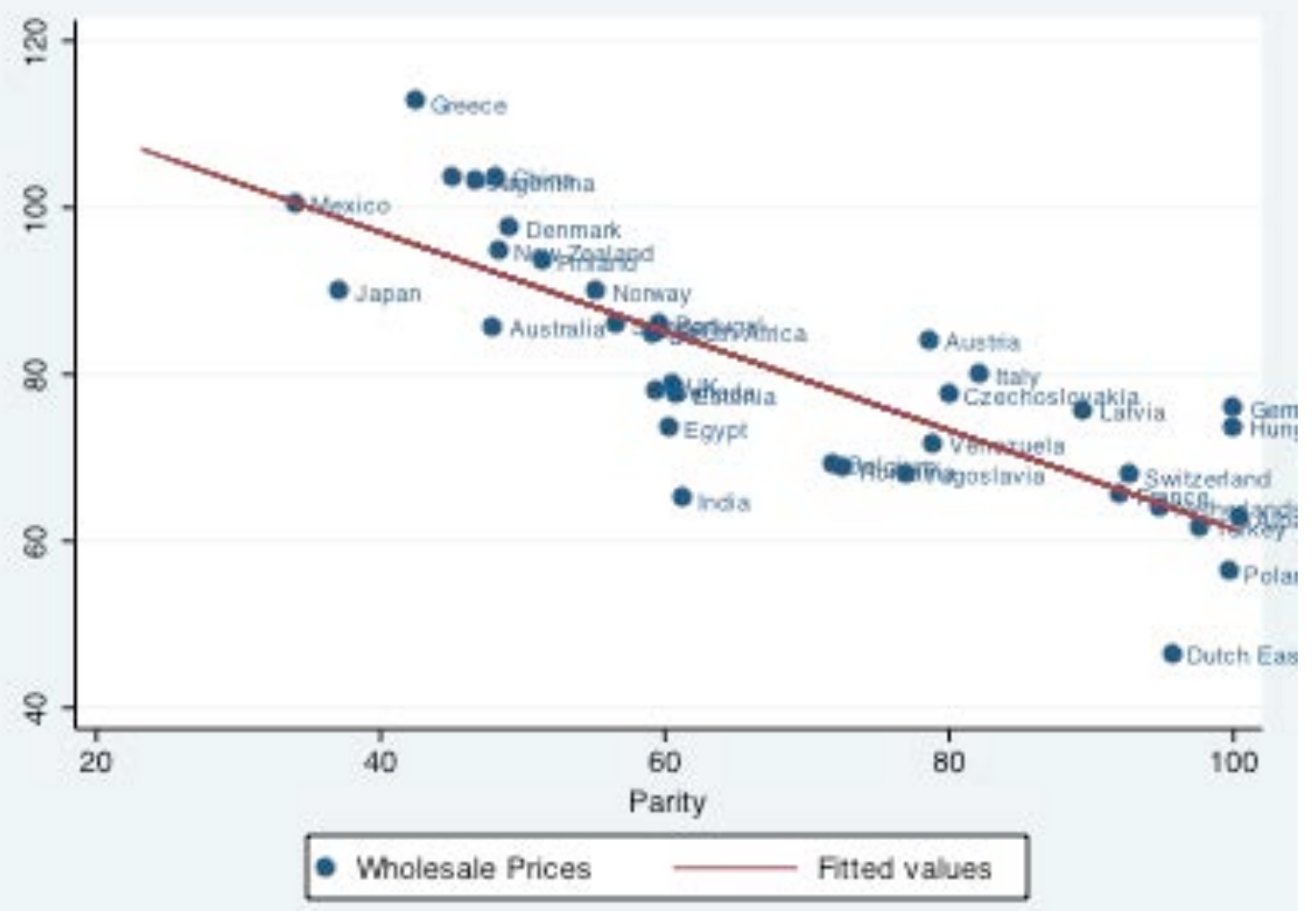


Figure 4: Exchange Rates and Exports, 1929-36

(1929=100)

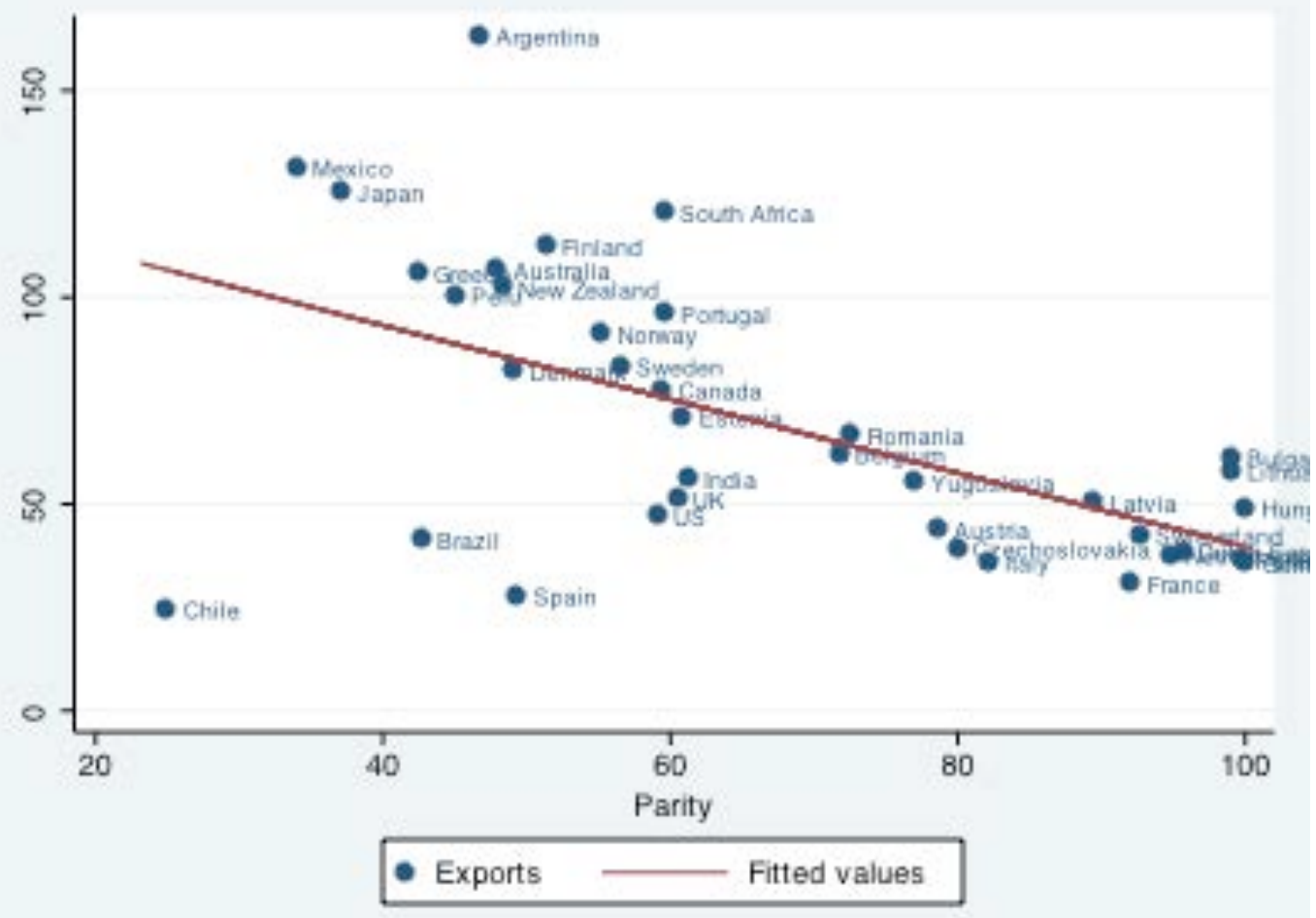

Figure 5: Industrial Production and Exchange Rates by Group, 1929-36

(1929=100)

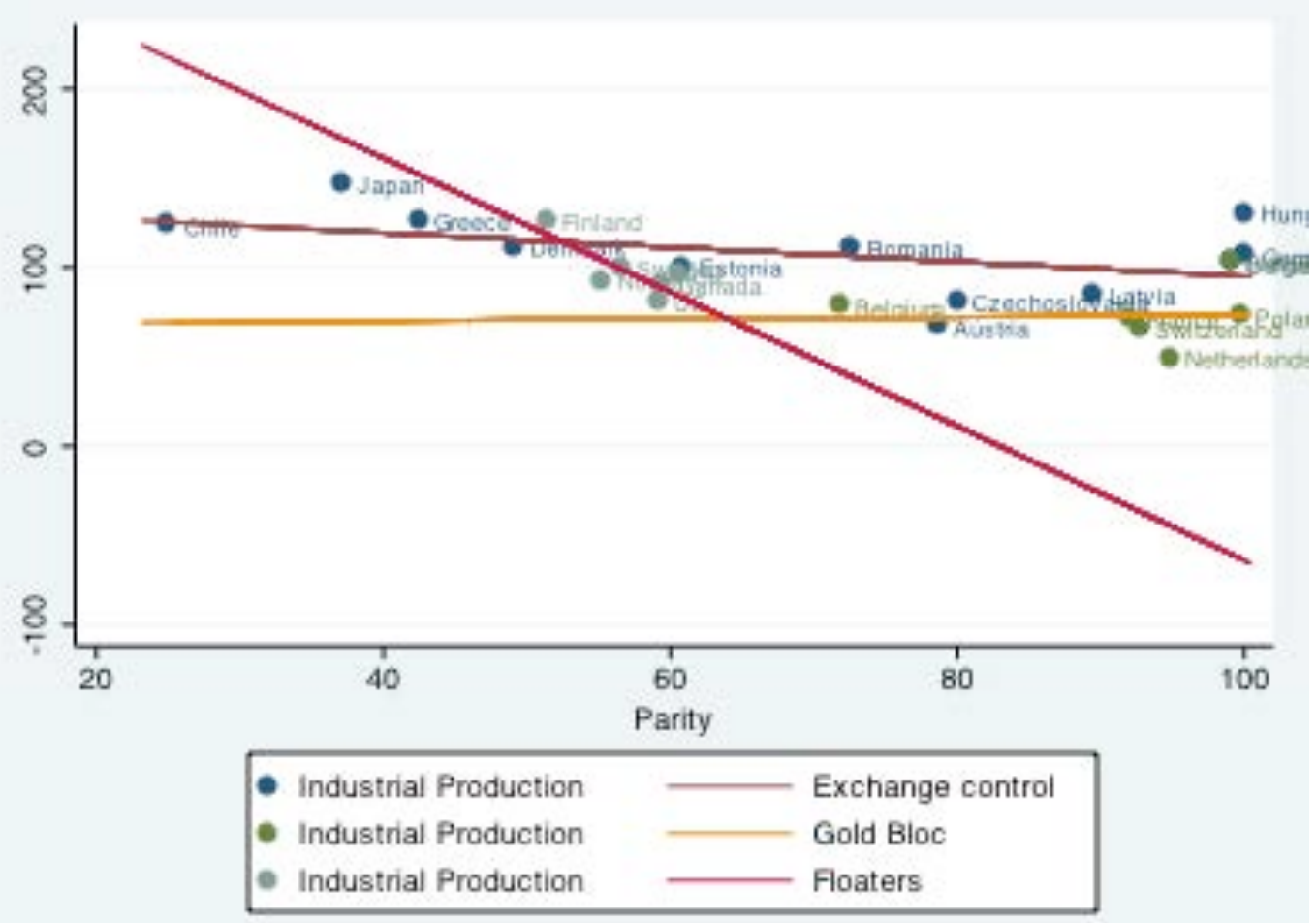


Figure 6: Wholesale Prices and Exchange Rates by Group, 1929-36

(1929=100)

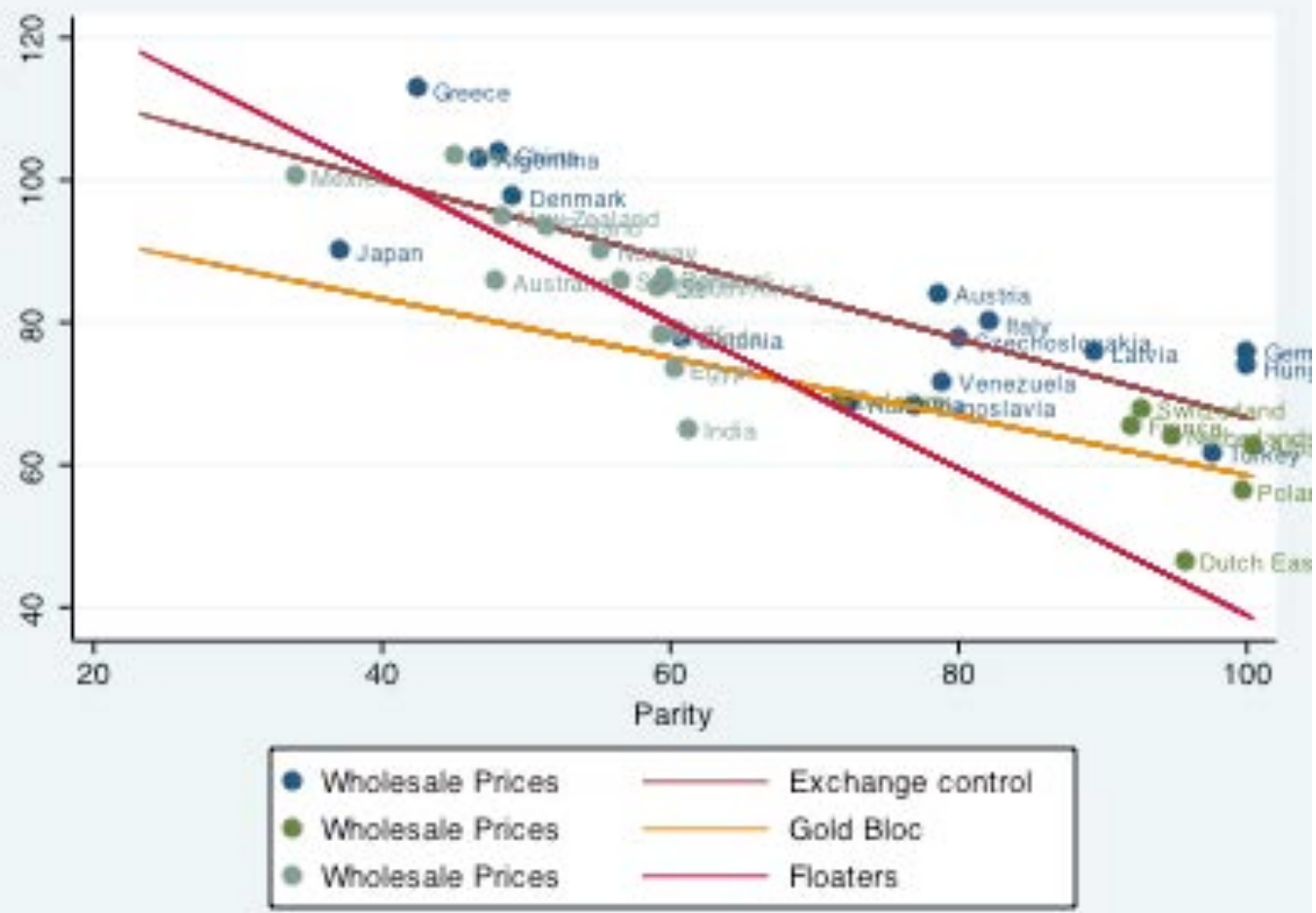

Figure 7: Exports and Exchange Rates by Group, 1929-36

(1929=100)

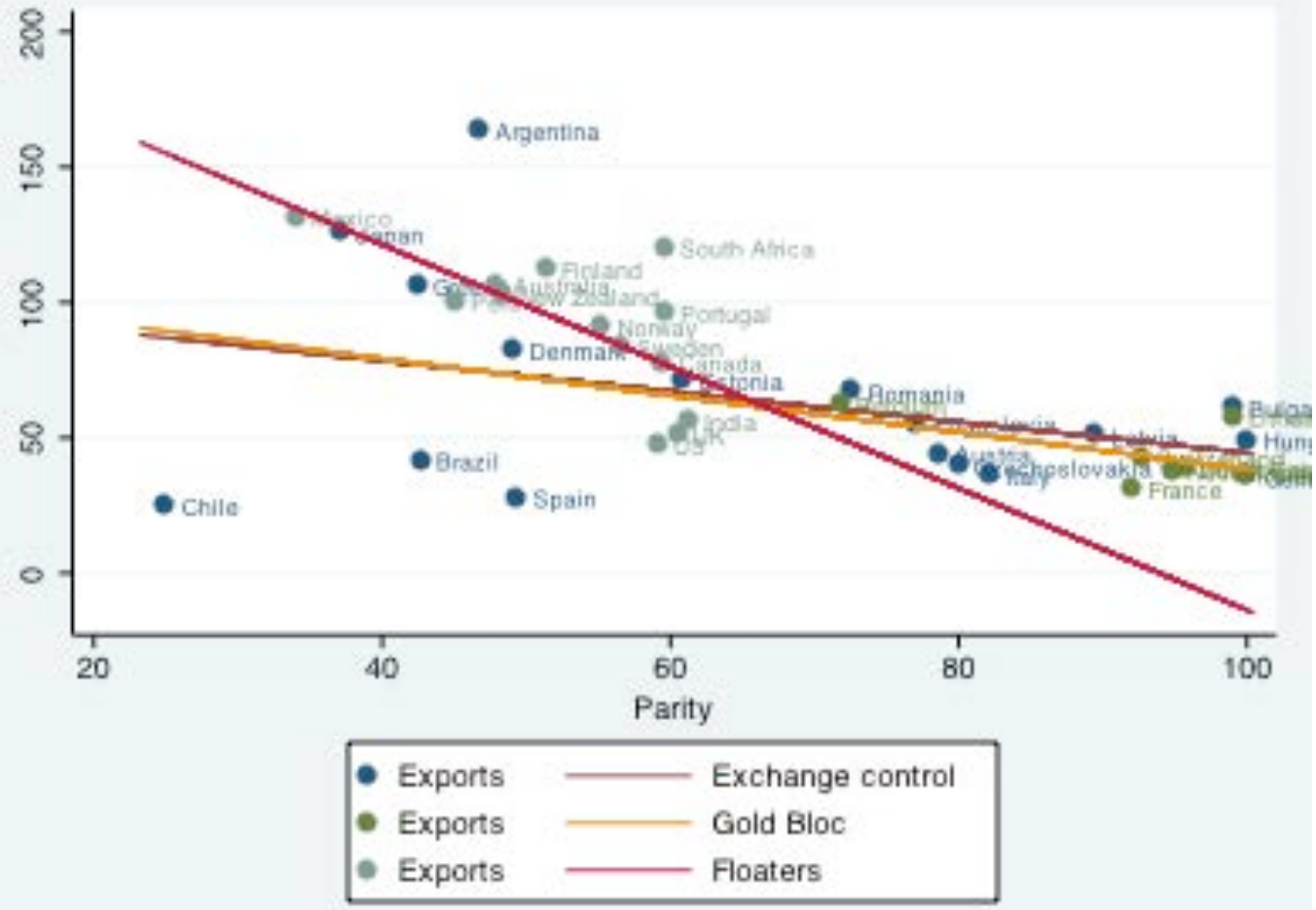


Figure 8: Average Growth in Industrial Production by Regime and Group

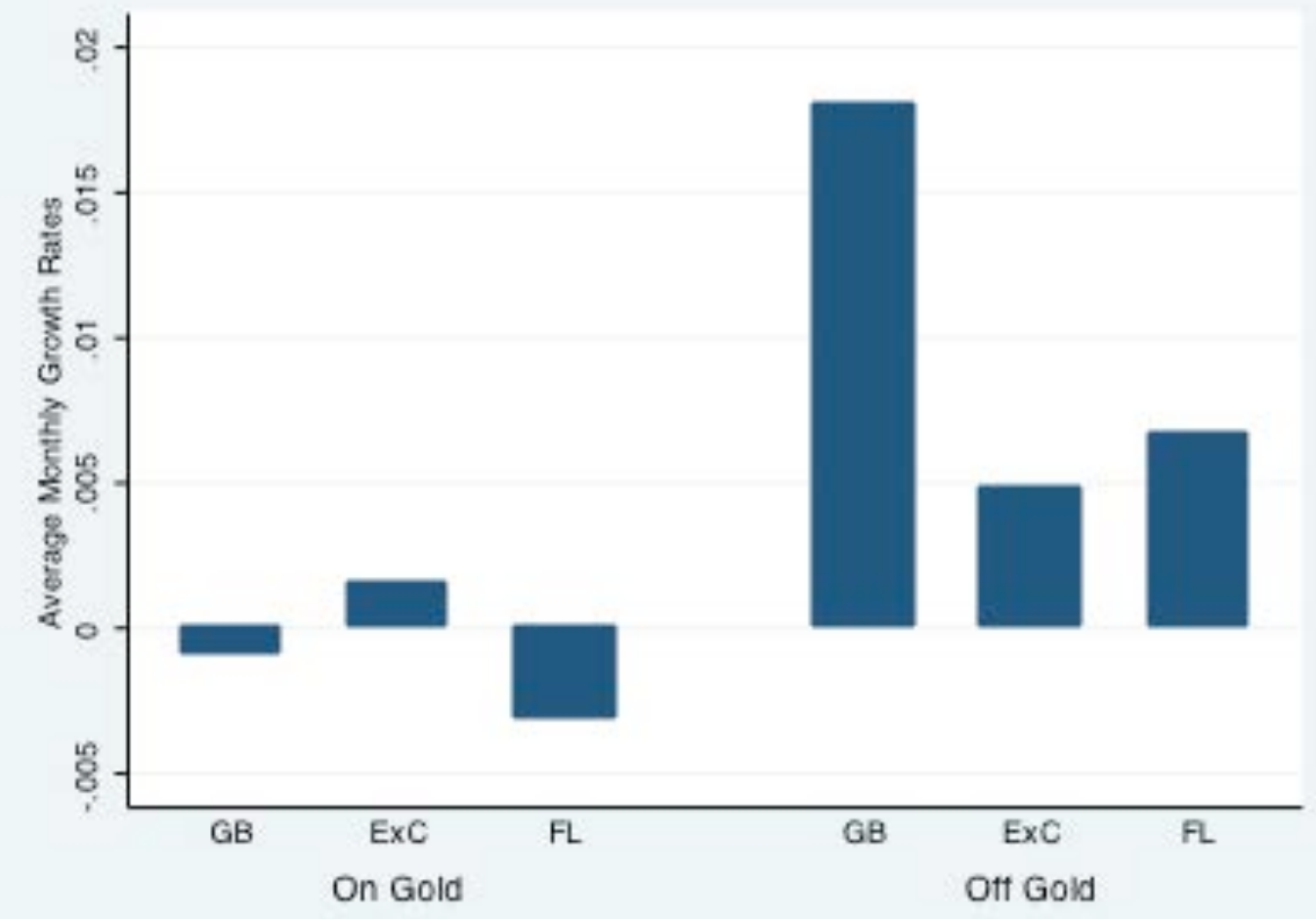

Figure 9: Average Inflation Rates by Regime and Group

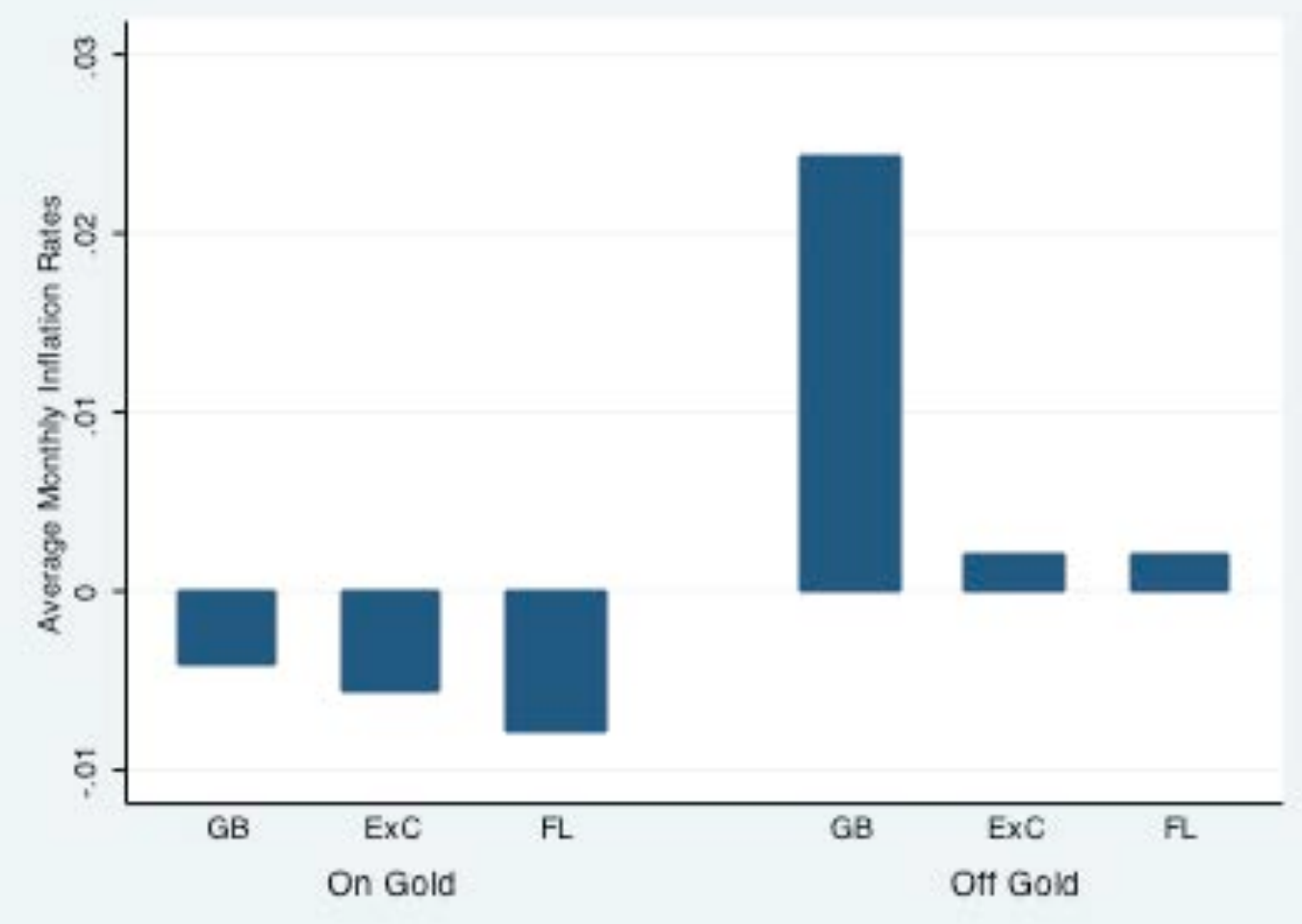


Figure 10: Average Export Growth Rates by Regime and Group

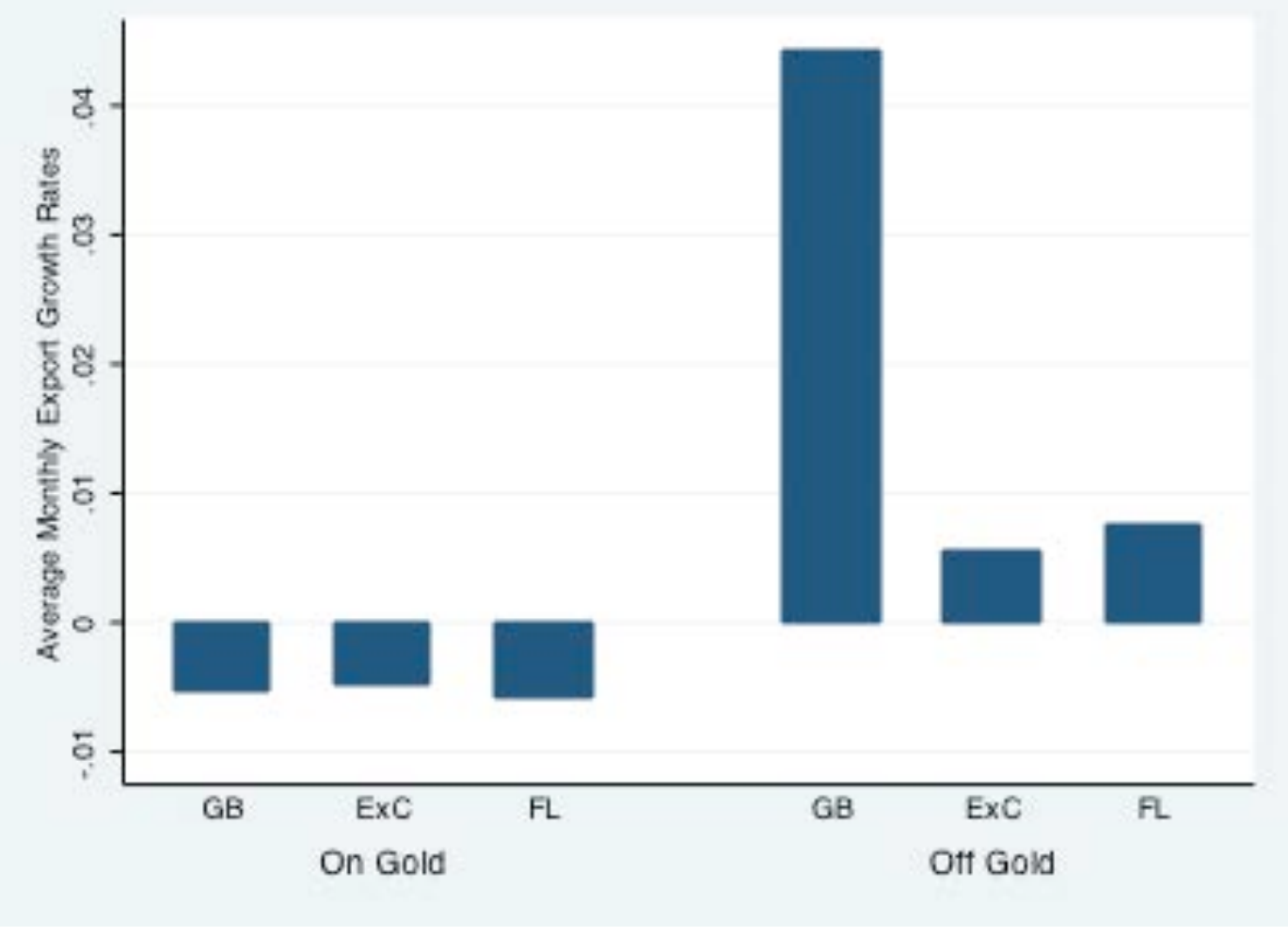

Figure 11: Average Money Growth Rates by Regime and Group

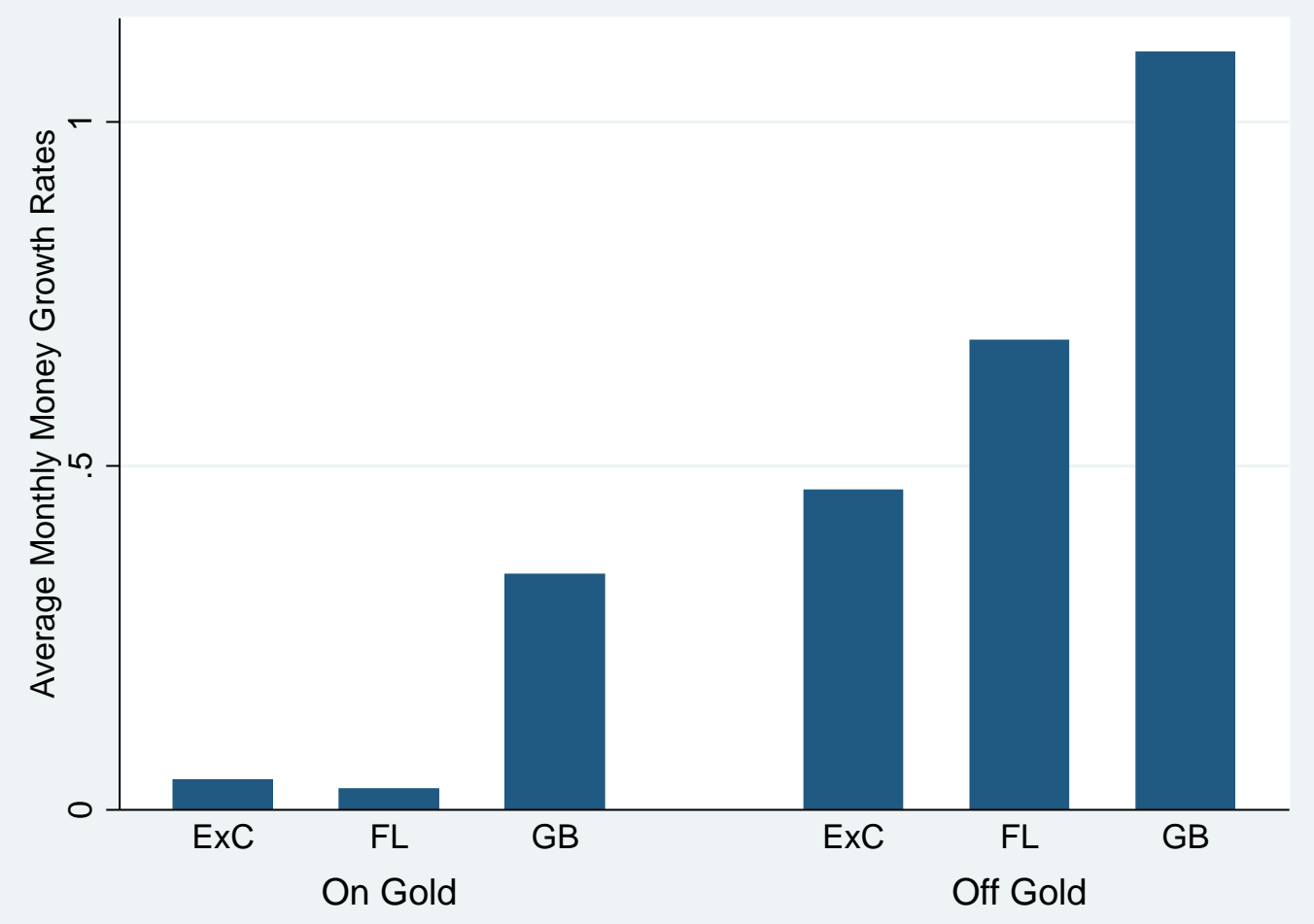

